Proc. Estonian Acad. Sci. Eng., 2001, 7, 2, 99-125

\title{
COMPARARISON OF GEOLOGICAL SETTINGS AT POSSIBLE DEEP HARBOUR SITES, NORTH-WESTERN SAAREMAA ISLAND
}

\author{
Jüri KASK, Helle PERENS, Rein PERENS, Sten SUUROJA, and \\ Andres KASK
}

\begin{abstract}
Geological Survey of Estonia, Kadaka tee 82, 12618 Tallinn, Estonia; j.kask@egk.ee, h.perens@egk.ee,perens@egk.ee, s.suuroja@egk.ee, andres.kask@ttu.ee

Received 2 March 2001, in revised form 22 March 2001

Abstract. The investigations carried out on Tagamõisa Peninsula (north-western Saaremaa Island, West Estonian Archipelago) were aimed at finding the deep harbour site with most favourable hydrogeological and geological conditions. Three possible sites were studied: Undva on the eastern coast of Uudepanga Bay, and Suuriku-Kuriku and Vaigu on the western coast of the Tagalaht Bay. The investigations show that in spite of active shore processes between Suuriku and Kuriku cliffs, geological and hydrogeological conditions for establishing the deep harbour are somewhat more favourable in this area than at Undva (dredging volumes as well as the amount of filling material needed for jetties and quays were not considered). At Undva dredging would be more workconsuming and to obtain fresh high quality drinking water is more complicated. Vaigu is less favourable because in the harbour basin area a thick layer of sand occurs on the seafloor.
\end{abstract}

Key words: deep harbour, Saaremaa Island, geological setting, bathymetric surveying, soil properties, hydrogeological conditions.

\section{INTRODUCTION}

Geological investigations serve as a basis for designing and construction of harbours. Depending on soil and rock properties as well as on hydrogeological conditions, most favourable solutions for the design of the harbour buildings, moles, and quays are chosen. The volume and cost of dredging, too, depend on the properties of soils and rocks forming the seafloor.

The research carried out on Tagamõisa Peninsula (north-western Saaremaa Island, West Estonian Archipelago) was aimed at finding the deep harbour site with most favourable hydrogeological and geological conditions $\left[{ }^{1}\right]$. Investigations were carried out at three possible sites: Undva on the eastern coast of 
Uudepanga Bay and Vaigu and Suuriku-Kuriku sites on the western coast of Tagalaht Bay (see inside back cover). The investigation area embraces the shore $200 \mathrm{~m}$ landward from the waterline and seafloor to the distance of $500 \mathrm{~m}$ from the waterline. To provide better understanding of the geological setting, a brief review of the bedrock and Quaternary deposits, as well as of hydrogeological conditions of the whole Tagamõisa Peninsula is presented. The review is based on geological mapping results carried out on the peninsula. Seafloor geological investigations have been previously carried out in Tagalaht Bay $\left[{ }^{2,3}\right]$ but these are of general character and the coastal area of possible deep harbour sites has not been considered.

\section{METHODS OF INVESTIGATION}

In the land area of potential deep harbour sites the following investigations were carried out:

- geodetic surveying,

- drilling to determine the thickness and properties of the Quaternary deposits as well as lithological composition of the bedrock,

- drillling of observation wells to investigate the hydrogeological conditions.

The geodetic base was geodetically marked with reference to trigonometric points. The coordinates are given in the L.Est 92' system and elevations in the Baltic system. The base elevations were obtained from the trigonometric points "Vaigu" $(\mathrm{H}=2.70 \mathrm{~m})$ and "Kuriku pank" $(\mathrm{H}=12.80 \mathrm{~m})$.

Tacheometry (scale 1:500) was carried out on Vaigu shore (0.4 ha) and in the area between Suuriku and Kuriku cliffs (1.5 ha) using electronic tacheometer Leica TCR-1105. Distances between profiles were measured with the 50-m BMI steel tape. Geodetic bases were composed using AutoCad 14.

During geological field work, the boundaries of possible harbour sites were geodetically marked using the plans with property borders obtained from the Kihelkonna Commune Authority. The investigation points were marked using tacheometer DAHLTA 010A and distances between profiles were measured with a steel tape.

During the preparatory phase of hydrogeological studies, reports of previous investigations carried out on Tagamõisa Peninsula were reviewed and the location of observation wells established. At Undva and Suuriku-Kuriku harbour sites the foundation of most buildings, as well as harbour basin constructions will be established on the bedrock. Therefore, vertical (to the depth of $10 \mathrm{~m}$ ) and lateral variability of limestone was thoroughly studied.

Drillholes were made by the UGB-1VS drilling rig. The Quaternary deposits were described in the process of drilling, while bedrock drillcores were stored for detailed investigations at the Keila Drillcore Depot of the Geological Survey of Estonia. In the total 21 drillholes were made on land area of the proposed harbour sites and additionally at each site one $10 \mathrm{~m}$ deep observation well was made for 
short-time test pumping and collecting water samples for general chemical analysis. During the field work period the hydrogeological conditions of the Tagamõisa Peninsula were investigated, and water level in wells and ground water electric conduction were measured. On the basis of these results, hydrogeological map of the area supplemented with two cross-sections was compiled.

On the seafloor (harbour basins) the following investigations were carried out:

- bathymetric surveying,

- mapping of bottom deposits distribution and composition,

- diving to specify the margins of the types of bottom deposits,

- drilling to determine the thickness and properties of the Quaternary deposits.

The bathymetric survey and topographic investigations of the seafloor were carried out using echo sounder-sonar Interphase PC/180 and echo sounder PEL-3. The latter recorded the seafloor topography on the paper tape. Investigation points of echo sounder survey were located by navigator Garmin12XL with differential block, using GPS (DGPS) corrections from Ristna differential GPS station on the frequency of $307.5 \mathrm{kHz}$, channel 48 . Investigations were carried out from a rubber boat (length $6 \mathrm{~m}$, width $2 \mathrm{~m}$ ).

Bottom deposits were sampled by a grip scoop and a corer specially designed for sampling of soft deposits.

Diving (swimming with aquaplane perpendicular to the waterline) was used at all harbour sites to specify the seafloor topography and margins between bottom deposit types. More detailed investigations of bottom deposits were performed at Undva at the depth of 8-11 m, where the Quaternary deposits were penetrated by a small hand drill. Due to low sea water stand during the field work period, drilling in shallow sea was partly carried out by a drilling rig mounted on a truck.

Investigations of the seafloor Quaternary deposits were carried out by REI Geotehnika Ltd., using floating dynamic probing equipment IGT 500 (weight of the hammer $63.5 \mathrm{~kg}$, falling height $50 \mathrm{~cm}$, cone cross-section area $16 \mathrm{~cm}^{2}$, Fig. $1^{*}$ ). Estimations of engineering-geological conditions further in the paper are based on the above investigation results $\left[{ }^{4}\right]$.

At Vaigu and Suuriku-Kuriku the investigation points (three at each site) on the nearshore were positioned perpendicular to the waterline. At Suuriku-Kuriku the first point was at a distance of $100 \mathrm{~m}$ and at Vaigu $200 \mathrm{~m}$ from the waterline while the following ones were placed at every $100 \mathrm{~m}$. Dynamic probing graphs for Vaigu harbour site are shown further in the paper. The respective graphs for Suuriku-Kuriku are not given because of small probing depth $(0.4 \mathrm{~m})$.

Grain size distribution of bottom deposits was determined by sieve analysis at the Laboratory of the Geological Survey of Estonia. It was estimated on the basis of the classification of terrigenous deposits proposed by Raukas $\left[{ }^{5}\right]$.

\footnotetext{
* Asterisks mark the coloured figures on unnumbered inserts.
} 


\section{GEOLOGICAL SETTING OF TAGAMÕISA PENINSULA}

\subsection{Bedrock}

On Tagamõisa Peninsula the rocks belonging to the Ninase Member of the Jaani Formation $\left(\mathrm{S}_{1} j n N\right)$ and the Vilsandi and Maasi beds of the Jaagarahu Formation crop out $\left[^{6}\right]$ (Fig. $2^{*}$ ). In the surroundings of the Undva Cape, in Uudepanga and Tagalaht bays also the marlstones of the Mustjala Member of the Jaani Formation and of the Velise Formation are exposed. This complex includes also the boundary beds of the Jaani and Jaagarahu stages that have been variously dissected by different authors $\left[^{7-9}\right]$. The above boundary beds comprise an about 30-40 m thick biohermal complex between the clearly distinguishable Mustjala Member of the Jaani Stage $\left(\mathrm{S}_{1} j n M\right)$ and the Maasi Beds of the Jaagarahu Stage $\left(\mathrm{S}_{1 j g M}\right)$.

\section{Velise Formation $\left(\mathbf{S}_{1} v l\right)$}

It is about $50 \mathrm{~m}$ thick and is made mainly of argillaceous marlstone, containing a few interbeds and nodules of argillaceous limestone.

\section{Jaani Formation $\left(\mathbf{S}_{1} \mathbf{j} n\right)$}

Mustjala Member $\left(\mathrm{S}_{1} j n M\right)$ comprises about $30 \mathrm{~m}$ thick marlstone complex overlying the Velise marlstones. These marlstone complexes form an about $80 \mathrm{~m}$ thick argillaceous complex (Fig. $3^{*}$ ), which due to the monoclinal bedding (beds are dipping southward) of the bedrock crop out on the seafloor to the north of Undva Cape. In the southern part of Tagamõisa Peninsula, the upper surface of the marlstone complex lies about $100 \mathrm{~m}$ from the ground surface. In the marlstones of the Mustjala Member, the content of carbonaceous material is higher than in the marlstones of the Velise Formation, containing numerous limestone interbeds $(5-50 \mathrm{~cm})$ in its upper portion.

Ninase Member $\left(\mathrm{S}_{1} j n N\right)$ covers the Velise and Mustjala marlstone complex. The 1.5-3.5 m thick layer of pure detrital limestone in its basal part is considered an important benchmark level of the region, its lower margin marking also the lower margin of the boundary beds of the Jaani and Jaagarahu stages. The described detrital limestone crops out in the northernmost part of the Tagamõisa Peninsula on the seafloor and is exposed in Undva, Suuriku and Kuriku cliffs. The topmost $12-15 \mathrm{~m}$ part of the Ninase Member is made of limestone containing different amount of argillaceous material, alternating with marlstone and biohermal limestone (detrital limestone and limestone rich in fossils).

\section{Jaagarahu Formation $\left(\mathrm{S}_{\mathbf{1}}\right.$ jg)}

Vilsandi Beds $\left(\mathrm{S}_{1} j g V\right)$. The boundary between the Jaani and Jaagarahu formations is conventional and lithologically unclear. On Tagamõisa Peninsula, the Vilsandi Beds are often rich in stromatopores and corals, forming bioherms that are exposed on ground surface at Undva. Presumably, similar bioherms form the cores of Kiipsaare Cape and Laevarahu Bank located to the west of the latter. Bioherm's 
host rock is mainly kerogenous argillaceous limestone, less often detrital limestone. The 12-15 $\mathrm{m}$ thick Vilsandi Beds are exposed in the Jaagarahu limestone quarry.

The basal part $(3-4 \mathrm{~m})$ of the Maasi beds $\left(\mathrm{S}_{1 j g M}\right)$, pure limestone with onkolites, serves as another benchmark level of the area. Total thickness of the Maasi Beds is $25-27 \mathrm{~m}$ and the remaining part is made mostly of argillaceous limestone, containing small coral bioherms. The Maasi Beds crop out in the central part of the Tagamõisa Peninsula. Near Kurevere there is a building limestone deposit where the Maasi limestone is produced for making shingle graded 400-600.

Both Uudepanga and Tagalaht Bay cut deep into the thick Mustjala-Velise marlstone complex, which is easily abraded (Figs. $3^{*}$ and $\left.4^{*}\right)$. These southerlyoriented bays have been formed in the places where the overlaying more resistant Ninase-Vilsandi limestone complex has been penetrated by fractures.

In Uudepanga Bay, the upper part (10-15 $\mathrm{m}$ ) of the nearshore consists of the resistant limestone complex, forming a bench reaching about 200-300 m into the sea. At Undva, in the underwater area the limestone complex is exposed as a narrow belt along the eastern coast of Uudepanga Bay to the depth of 6-8 m. Further on, it is covered by the Quaternary deposits. In the central part of the bay (depth over $20 \mathrm{~m}$ ), less resistant marlstones of the Jaani Stage crop out. At Suuriku-Kuriku, mainly the marlstones of the Jaani Stages occur on the seafloor, while at Vaigu marlstones are covered by the limestone complex. The surface of the latter is gently dipping till the underwater escarpment. Deeper than 10-12 m, the marlstones of the Mustjala Formation crop out.

By geological setting, Tagalaht Bay belongs to the Silurian (West Estonian) Klint, which begins on Kessulaid Islet, extending over northern Muhu and Saaremaa islands. Tagalaht Bay, cutting deep inland with cliffs on capes, displays the characteristic features of klint bays. It is exposed to the north and the nearshore is steep, especially on the western coast where two escarpments occur (the upper one is located higher on the shore). In central part of the bay, the seafloor is dipping gently towards the baymouth.

The same lithological units as on the seafloor spread on the shore, except that the marlstone complex crops out on a very small area in the lower section of Undva and Suuriku cliffs as a 1-2 m thick bed (Fig. $4^{*}$ ).

On the shore, the biohermal complexes of variable composition, belonging to the Ninase Member of the Jaani Stage or Vilsandi Beds of the Jaagarahu Stage, crop out at all harbour sites forming plateaus or steep escarpments. Total thickness of the biohermal complex reaches about $30 \mathrm{~m}$. The elongated bioherms are of massive texture, their length reaching 10-20 m. These are made of limestone containing abundant bryozoas and corals, and is dolomitized in places. The host rocks are pure strong detrital limestone, argillaceous limestone, marlstone, and kerogenous limestone.

At Undva the Quarternary cover is very thin or missing (alvars). The topmost 4-8 $\mathrm{m}$ of the bedrock is the biohermal limestone complex belonging to the Jaani Stage. Its upper part is made of argillaceous limestone with bioherms, which can be 
used as filling material. The lower, about $2 \mathrm{~m}$ thick, part consists mainly of strong pure limestone usable as building stones. This level is easily distinguishable in all drillholes of the region.

Geological setting of the Suuriku-Kuriku harbour site is similar to Undva, except that the bedrock forms two 10-12 m high cliffs; the planned harbour is located between these. The limestone escarpment is retrograding, since the less resistant argillaceous limestone is abraded by the sea. The margin of the upper biohermal complex (about $10 \mathrm{~m}$ ) and underlying marlstones of the Jaani Stage approximately coincides with the average waterline. Thus on the seafloor the marlstones of the Jaani stage crop out. Suuriku and Kuriku cliffs have been accounted as nature monuments and the designed buildings must not damage these.

At Vaigu, too, the bedrock is represented by the biohermal complex of the Jaani Stage with argillaceous limestones in its upper and pure limestone in the lower part.

According to previous investigations carried out in the area $\left[{ }^{10}\right]$, uniaxial compressive strength of the argillaceous limestone (upper part of the biohermal complex of Ninase Formation of the Jaani Stage and Vilsandi Beds of the Jaagarahu Stage) is $40-60 \mathrm{MPa}$, while that of the pure limestone in the lower part of the complex reaches $60-80 \mathrm{MPa}$. Uniaxial compressive strength of the marlstones of the Mustjala Member (Jaani Formation) is $20-25 \mathrm{MPa}$ and that of the argillaceous marlstone interbeds 30-50 MPa.

\subsection{Quaternary deposits}

\subsubsection{Shore processes}

Shore processes are controlled by the geological setting and hydrodynamical conditions of the area, i.e., by the deposits forming the shore, and by the extent the shore is exposed to prevailing winds. On the western coast of Saaremaa Island westerly and south-westerly winds prevail. Consequently, both Tagalaht Bay and Uudepanga Bay are sheltered from these. On the other hand, the bays under observation are exposed to northerly winds, causing coastal damages, sediment transport and accumulation (Fig. $5^{*}$ ).

Shore processes on the eastern coast of the Tagalaht Bay have been investigated by Orviku $\left[{ }^{11}\right]$ and the review in the present paper is based on this study. Shore processes in the above area are intense, first of all due to steep nearshore. Generally, the eastern coast of the Tagalaht Bay is shallow and gently dipping, while the western coast is much steeper, with an escarpment on the shore. On eastern coast the bedrock is exposed in places, while the escarpment on the western coast has formed in the Quaternary deposits. On the north-western coast there are two intensely abraded cliffs - Suuriku and Kuriku. On the eastern coast, between Ninase Cliff and Kugalepa there is pebbly shore, the material originating from Ninase Cliff. Southward of Kugalepa, several beach ridge systems are found, separated from each other by small coves. The described ridge systems have been formed during different Baltic Sea development stages, their material originating from the bordering seafloor (the particles are poorly 


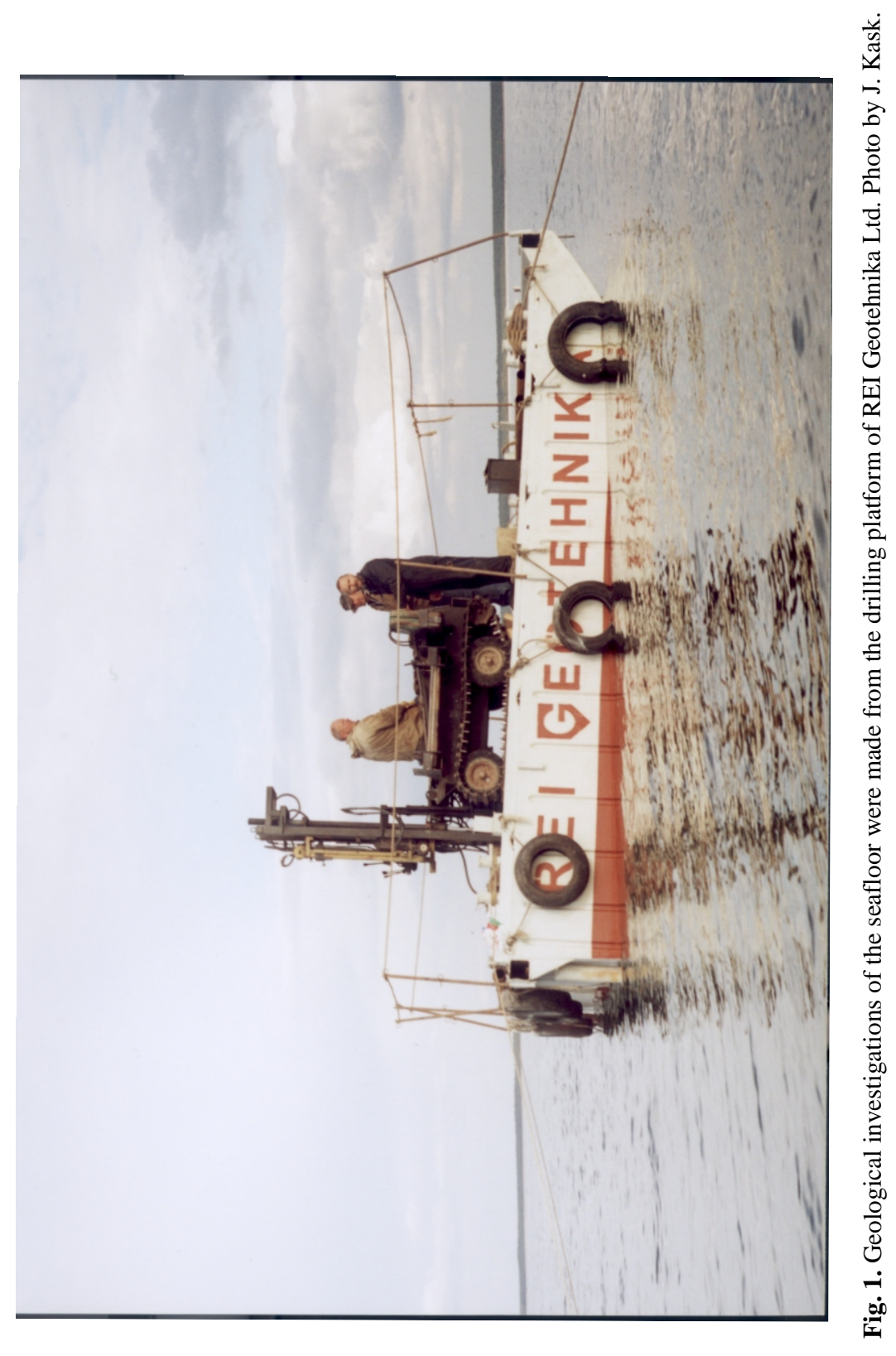




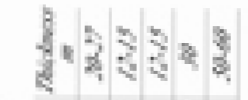

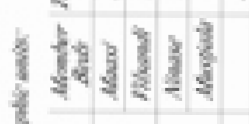
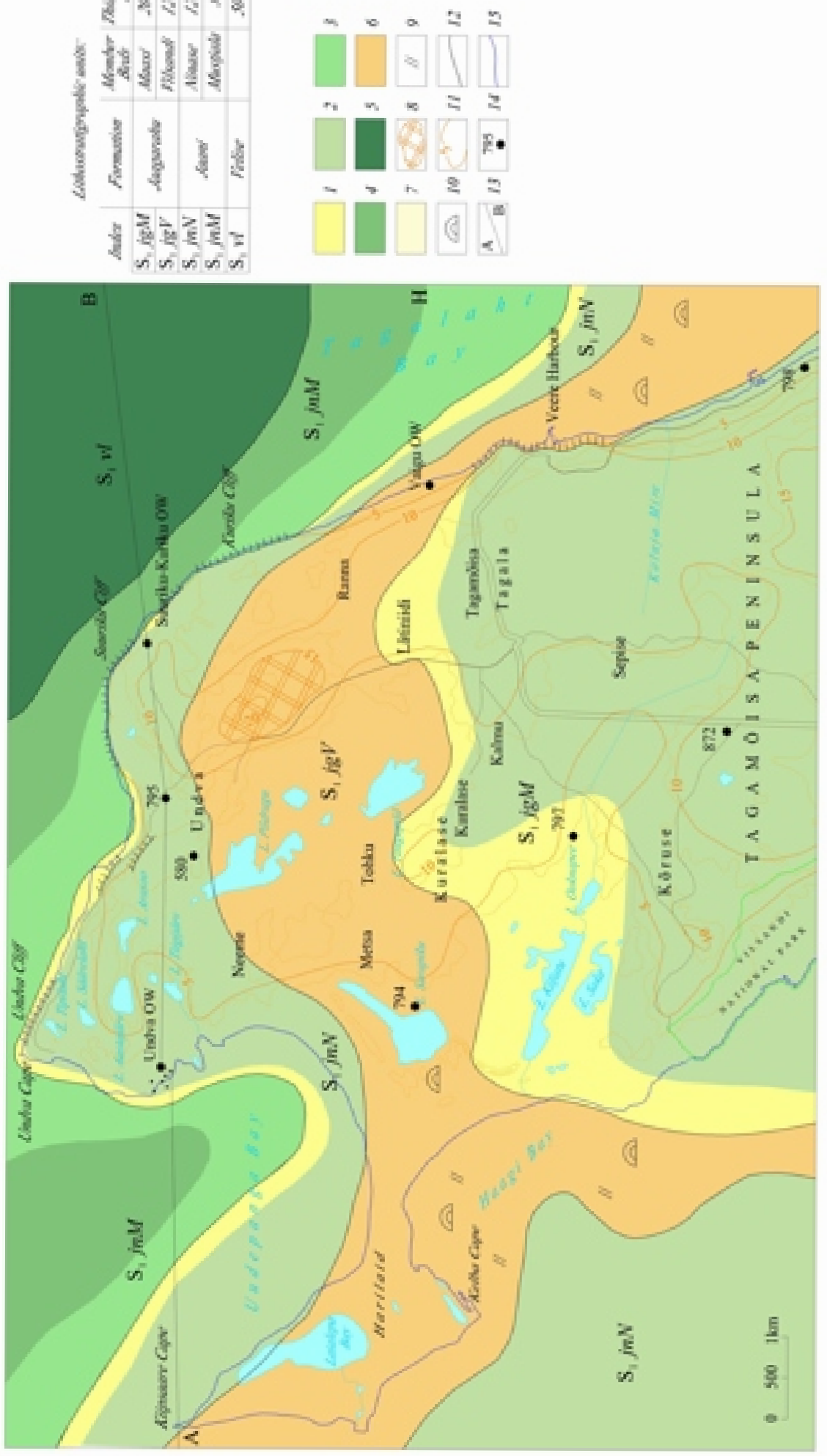

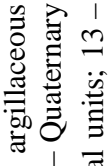

ㅅ․ㄹ

泀

$\because 8$

।

- 忽二

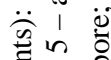

ฮี के

를 올

क $\Xi$

的气

总选

ฮ

吾 1 过

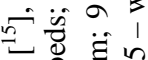

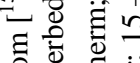

过曽

을 용

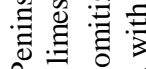

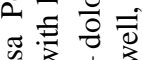

㣢范 1

สิ $\ldots$

焉蓄

¿ 䒕

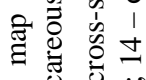

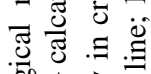

응 $\mathrm{m}$ 츨

¿ั0

i 范

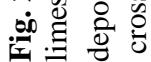




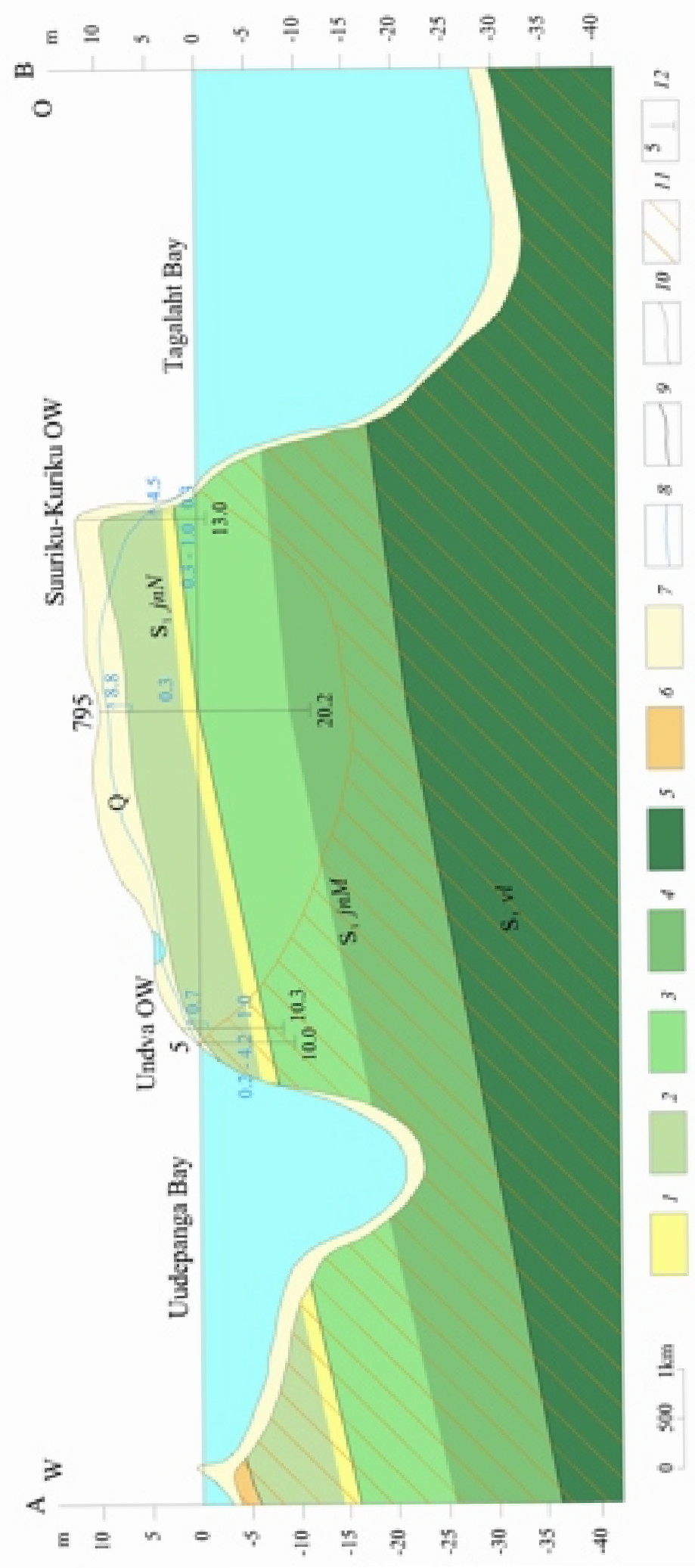

言言

寻

菏

ส

호응

可:

기 11

$\sim \ddot{0}=$

它产高

\&

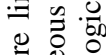

訰

语:

范

击 的

巳

产

is

总客

表热

가요

实

过

ㄱ.

宝

\&

혜

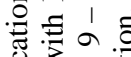

。․

훙

击离密

。

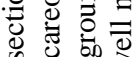

is

ơ 1 is

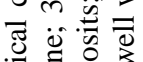

60

잉

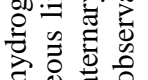

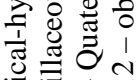

.5

승

ஸे

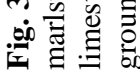




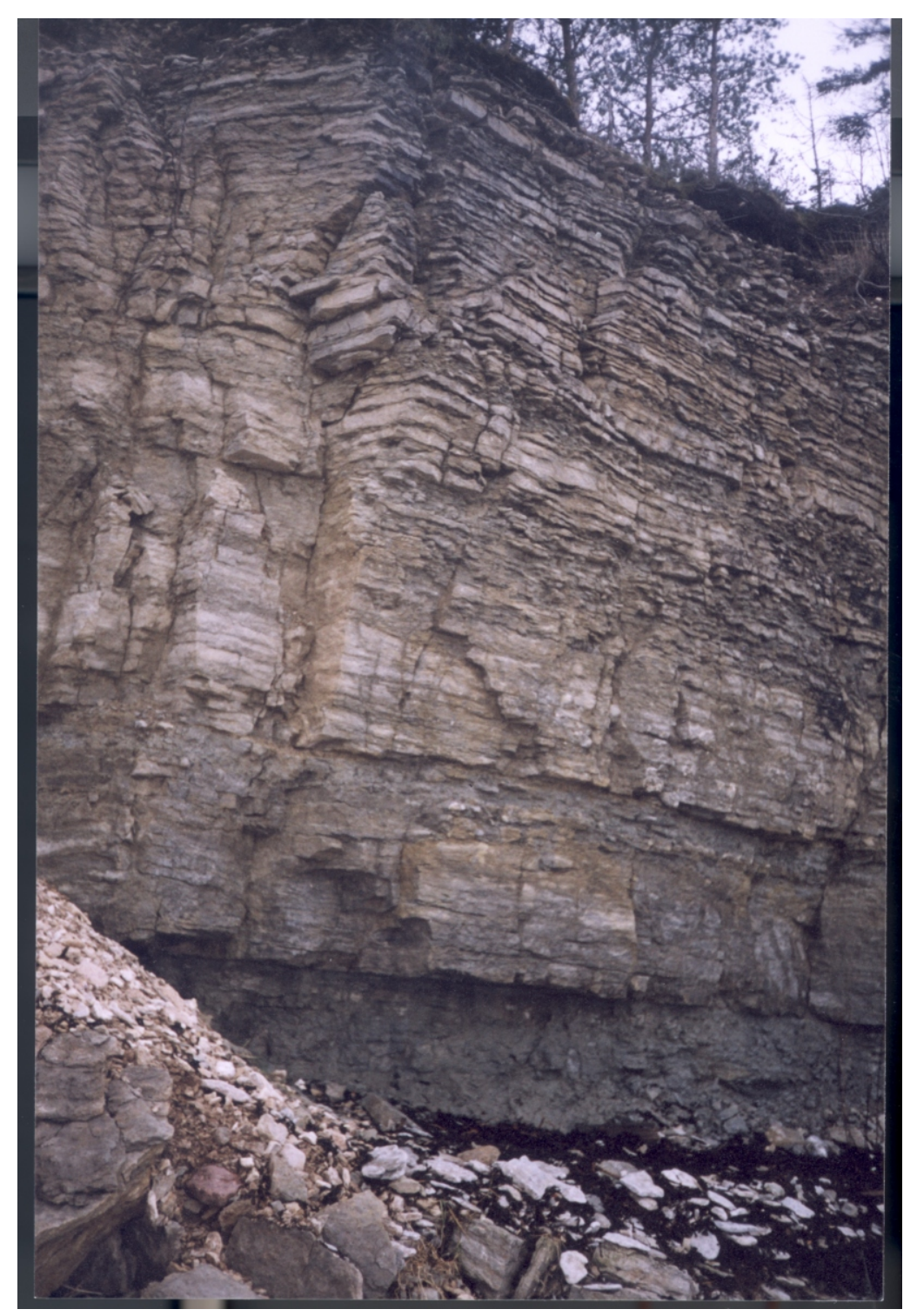

Fig. 4. Suuriku Cliff. Photo by H. Perens. 


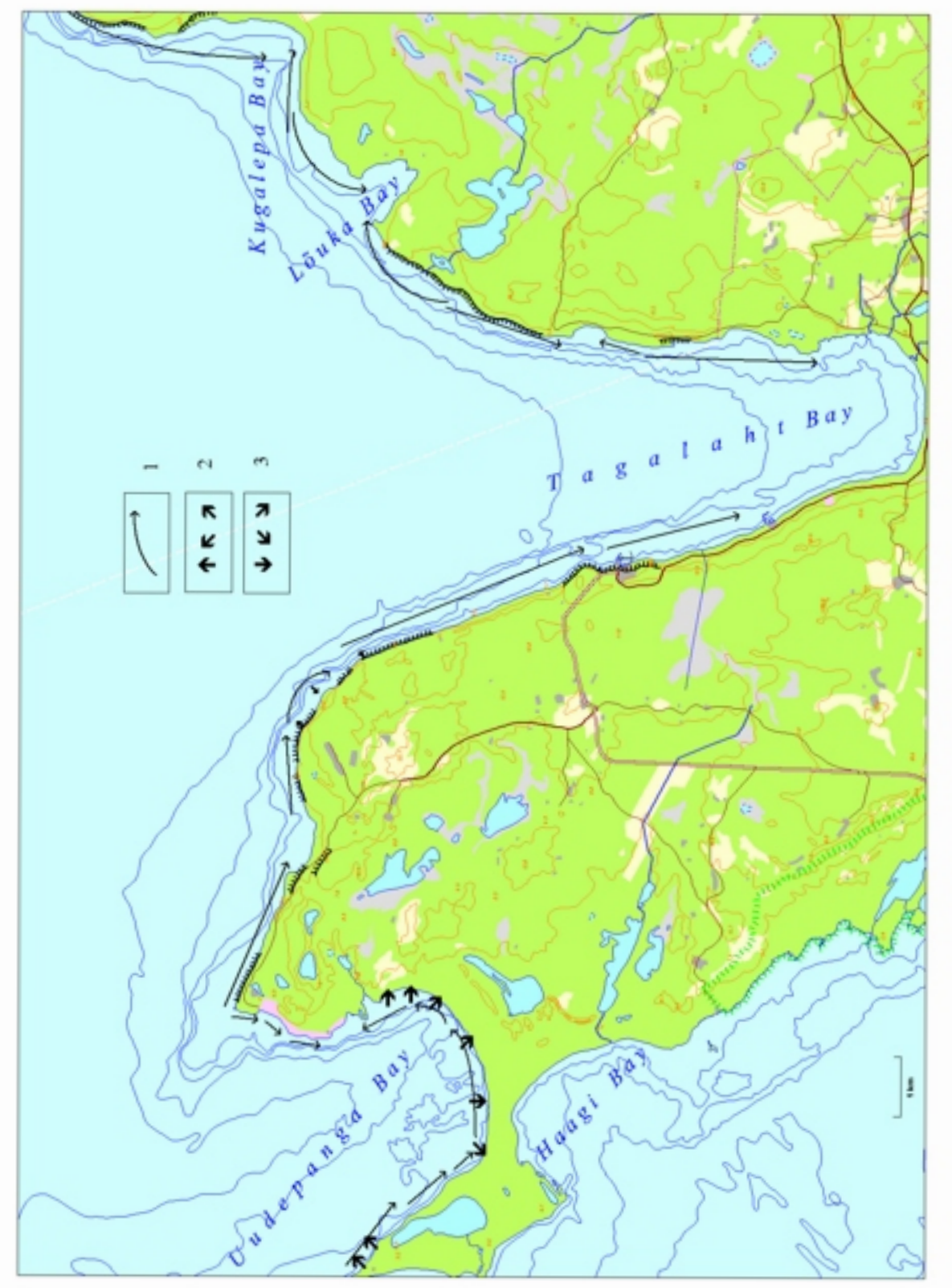

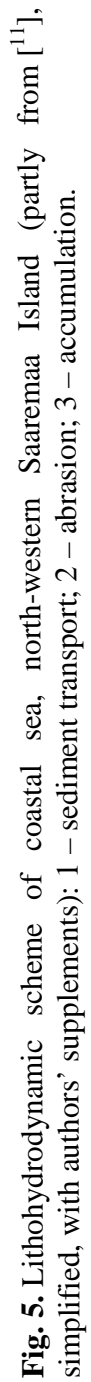




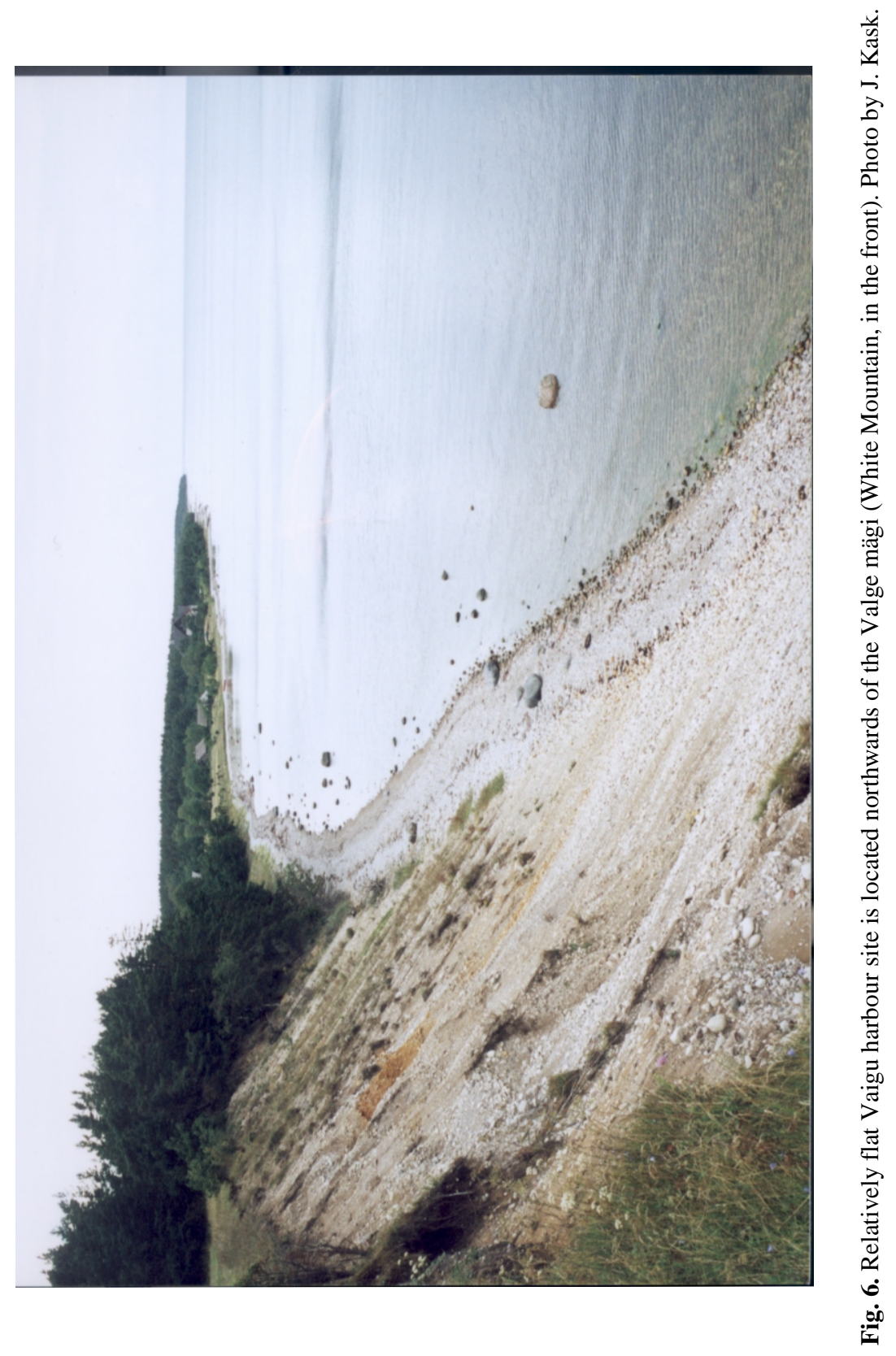




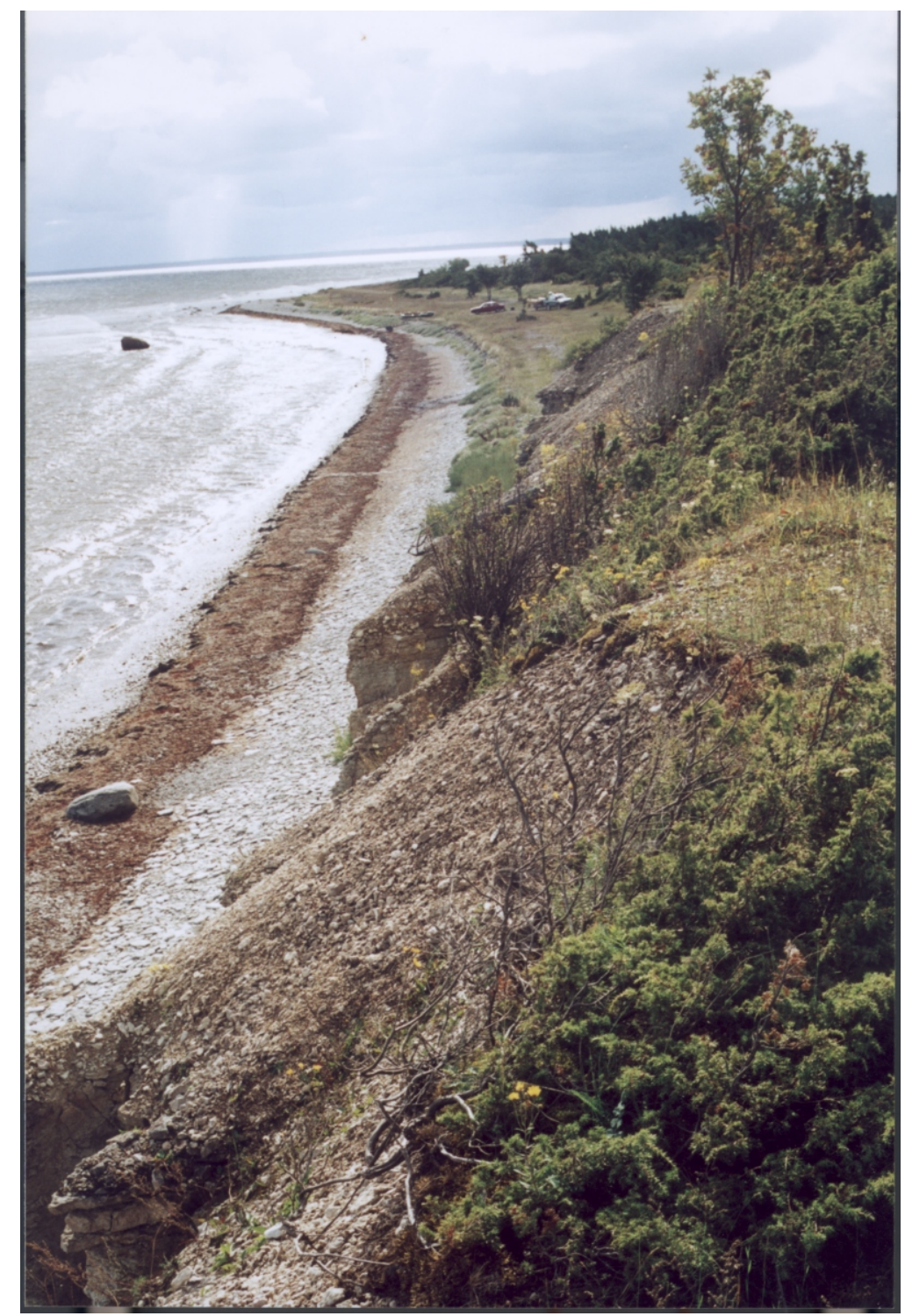

Fig. 7. Suuriku-Kuriku harbour site is partly situated on coastal plane covered with shingle beach ridges. Photo by J. Kask. 


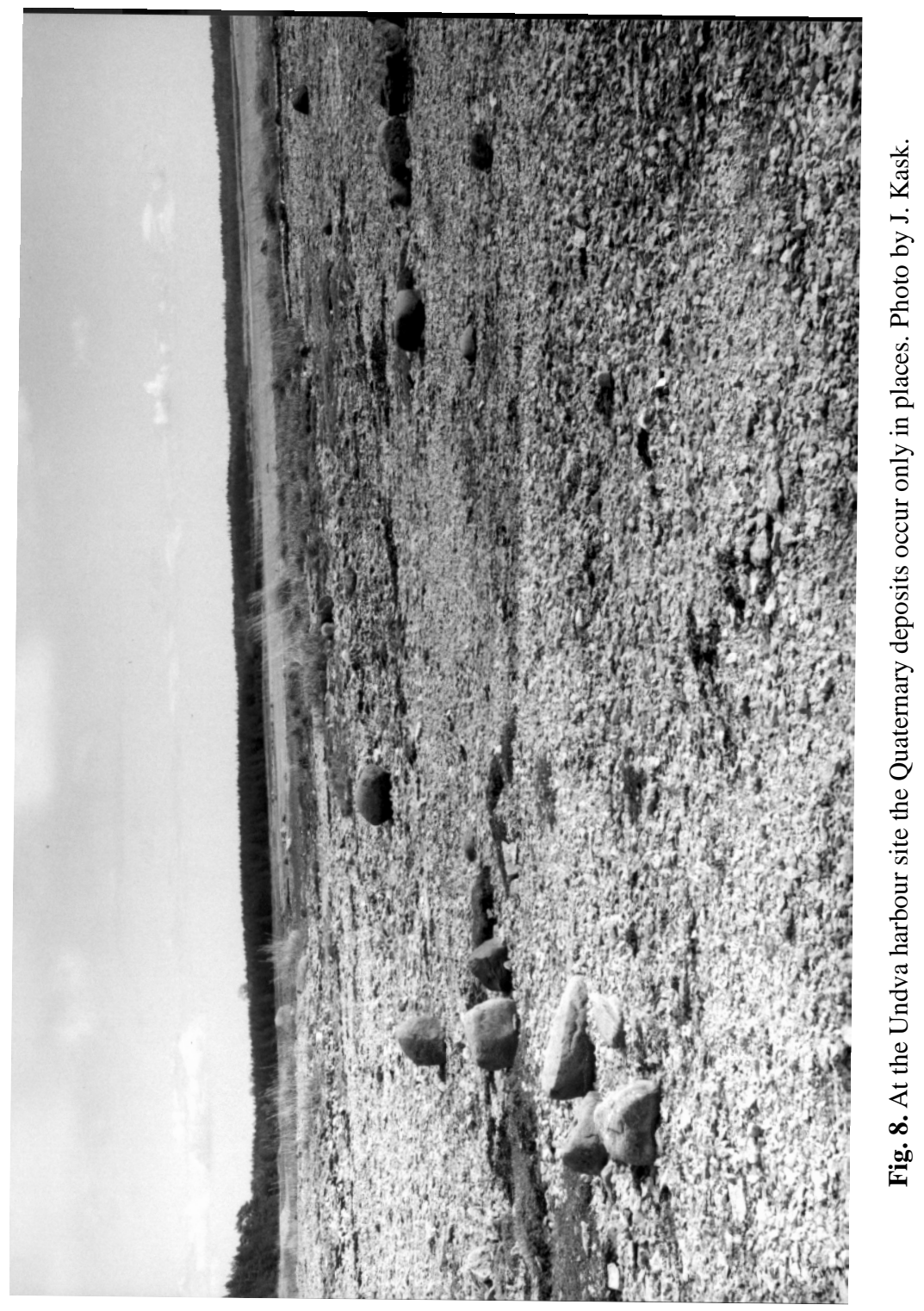



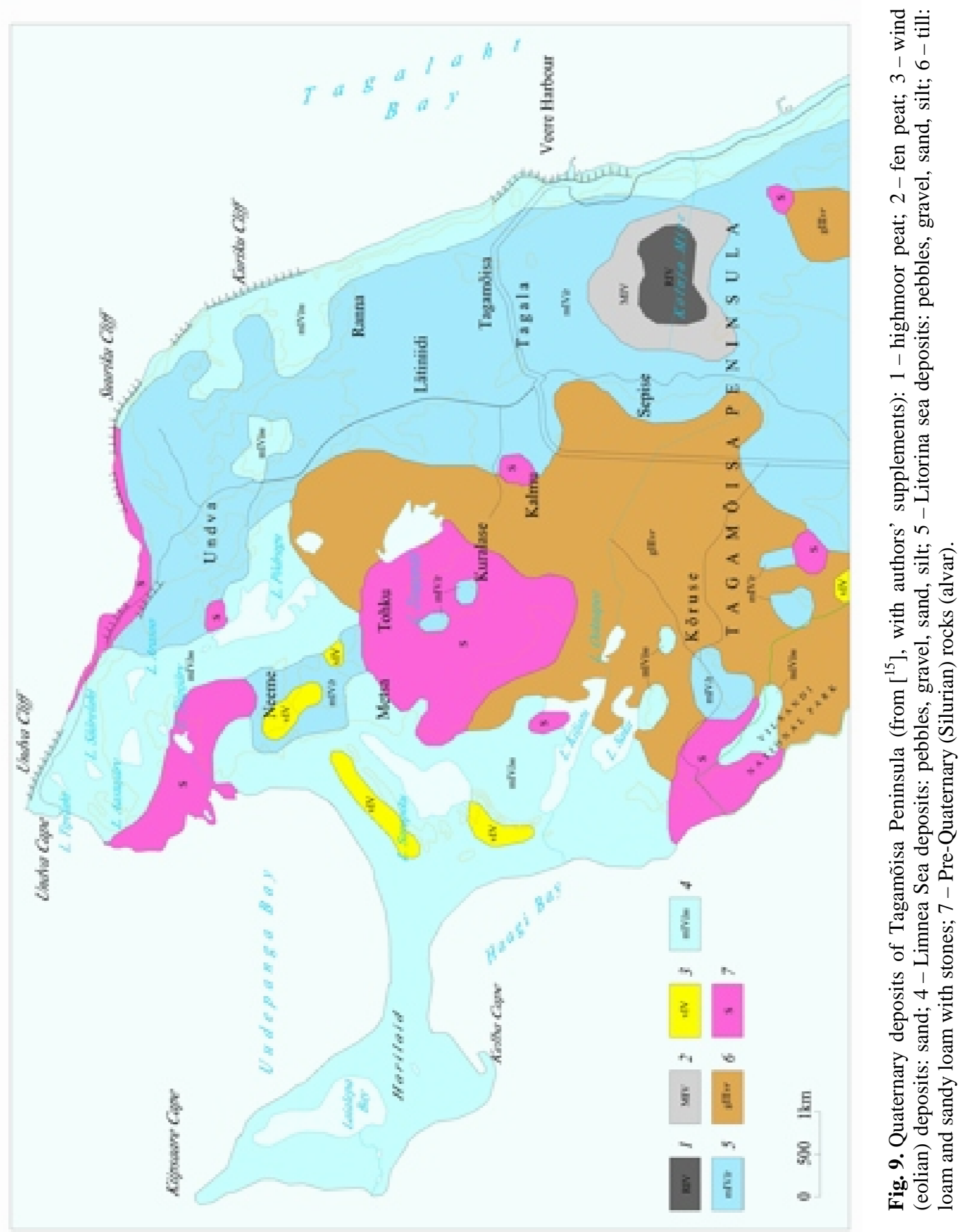


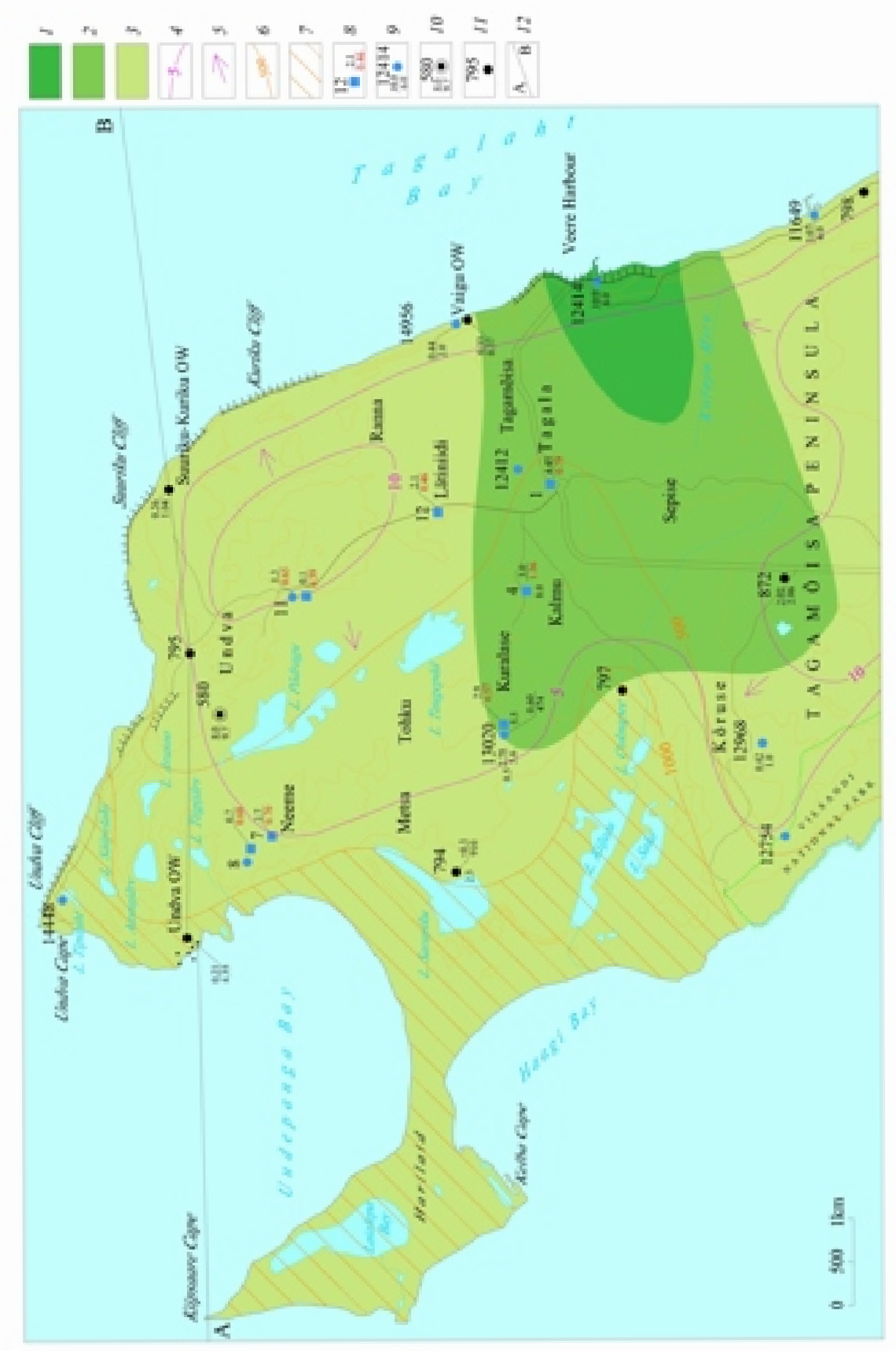

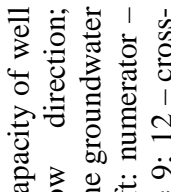

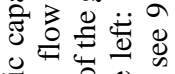

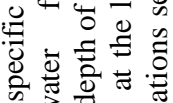
130.5

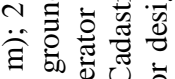
造证 的春

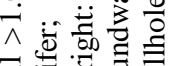

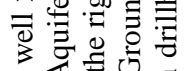
安过 预. जี

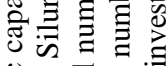
웡

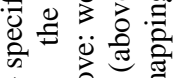
1 吠

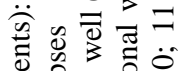
을

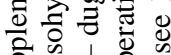

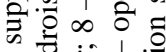

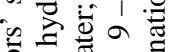

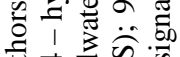

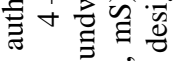

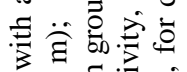

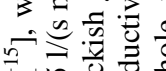
융유용

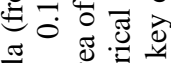

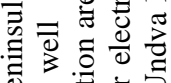
巳

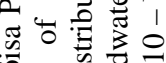
盇

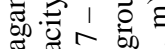
额

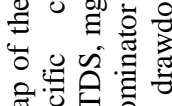

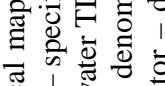

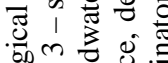

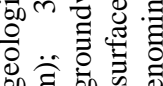

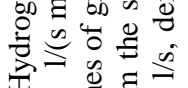

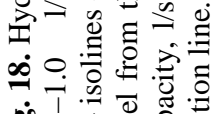
분? 
rounded). More detailed investigations have shown that the above beach ridge systems have developed lithodynamically independently $\left[{ }^{11}\right]$. In the bayhead of the Tagalaht Bay there is a sandy shore with foredunes. Along the western shore, northward appears relatively gently dipping pebbly shore up to Kesknõmme. After that the height of the escarpment increases, reaching its maximum height on the Valge mägi (White Mountain, Fig. $6^{*}$ ). The latter is an elevation, made of light-coloured limestone pebbles, gravel, and sand which has been abraded by the sea, forming an about $15 \mathrm{~m}$ high escarpment. In this area intense erosion takes place and the material is carried to the south. This is confirmed by the accumulation of material at the mole of the Veere Harbour, and also by earlier investigations $\left[{ }^{11}\right]$. Some sand and gravel accumulated here have been used as building material and therefore the present accumulational landform has not been preserved naturally. Southward of the Veere Harbour the coastal escarpment is abraded and the material is carried towards the south.

Near the Vaigu village the shore flattens (Fig. $6^{*}$ ). The contemporary beach ridges consist mainly of the limestone shingle and pebbles. Similar material is found also on the foreshore. On younger beach ridges no vegetation is observed, while the older (located landward) are covered with forest. Surface rises by about $12 \mathrm{~m}$ on the $200 \mathrm{~m}$ wide shore area.

Suuriku-Kuriku harbour site is located on a relatively flat area between Suuriku and Kuriku cliffs (Fig. 7). Material of the coastal ridges originates mainly from the Suuriku Cliff which is abraded by storm waves during high water levels. Abundant cobbles and pebbles are found on the shore and nearshore. The eroded material is carried southward on the nearshore. The latter is confirmed by the fact that the rounded pieces of bricks from the wreck near Suuriku Cliff are found in beach ridges about $1-1.5 \mathrm{~km}$ southward. The low and flat area suitable for establishing harbour buildings is only about 50-60 m wide. Further on landward, the ground surface rises rather steeply, reaching about $12 \mathrm{~m}$ at a distance of $200 \mathrm{~m}$ from the waterline.

Undva Cliff is situated on the north-western coast of the Tagamõisa Peninsula. The material abraded from this cliff is carried mostly eastward, to a lesser extent southward, towards the inner part of Uudepanga Bay [ $\left.{ }^{1}\right]$. At the Undva harbour site, the original beach ridges made of limestone shingle are poorly preserved since they have been removed or used as a road base (Fig. $8^{*}$ ). Single low (height $0.5-$ $0.7 \mathrm{~m}$ ) beach ridges formed during storms are found on the shore. These have been formed from the limestone material abraded from the limestone beds exposed on the seafloor. The amount of shingle and pebbles transported in this way is, however, small. On the western coast of the Tagamõisa Peninsula (from the Undva Cliff up to about 200-300 m southward of the abandoned lifeboat station's mole), limestone crops out on the nearshore. In places it is covered by up to $10 \mathrm{~cm}$ thick layer of marine sediments. Formerly, two harbour sites were known in the Uudepanga Bay: the above mentioned life boat station and a small cove near the Neeme village. The first of these is presently abandoned, while the other is still used by small vessels. About $1.5 \mathrm{~km}$ southward of the planned Undva harbour site begins 
sandy shore, extending over the bayhead and Harilaid Peninsula up to the Kiipsaare Cape. On the western coast of the Uudepanga Bay, intense transport of sand is observed. The shore is abrasional-accumulational, as evidenced by the traces of damages in old dunes on the Kiipsaare Cape. The sediment material is transported towards the bayhead. The latter together with the eastern coast of the Harilaid Peninsula form an independent lithohydrodynamical system, which is not directly related to the processes on the eastern coast of the Uudepanga Bay.

\subsubsection{Quaternary deposits in land areas of the harbour sites}

On most of the Tagamõisa Peninsula, the Quaternary cover is thin. The bedrock is covered by till, and this in turn by the Limnea and Litorina Sea deposits (sand, shingle, pebbles) (Fig. 9*). Dunes are found only in the north-western part of the peninsula, while in its eastern part there is Kõlaja Mire (thickness of peat layer mainly 1-2 m). Total thickness of the Quaternary cover is mainly 2-3 m, reaching $5-6 \mathrm{~m}$ only on the eastern coast between Veere and Vaigu. At Undva the Quaternary cover is very thin or missing (alvars).

At Suuriku-Kuriku the cross-sections on the land and seafloor were connected to the drillhole (DH) 2-1 on profile 2 (only $0.17 \mathrm{~m}$ above the average water level, Fig. 10). In this drillhole, thickness of the Quaternary deposits is $0.80 \mathrm{~m}$, while in DH 2-2 (landward along the same profile) it reaches $2.80 \mathrm{~m}$. After that,

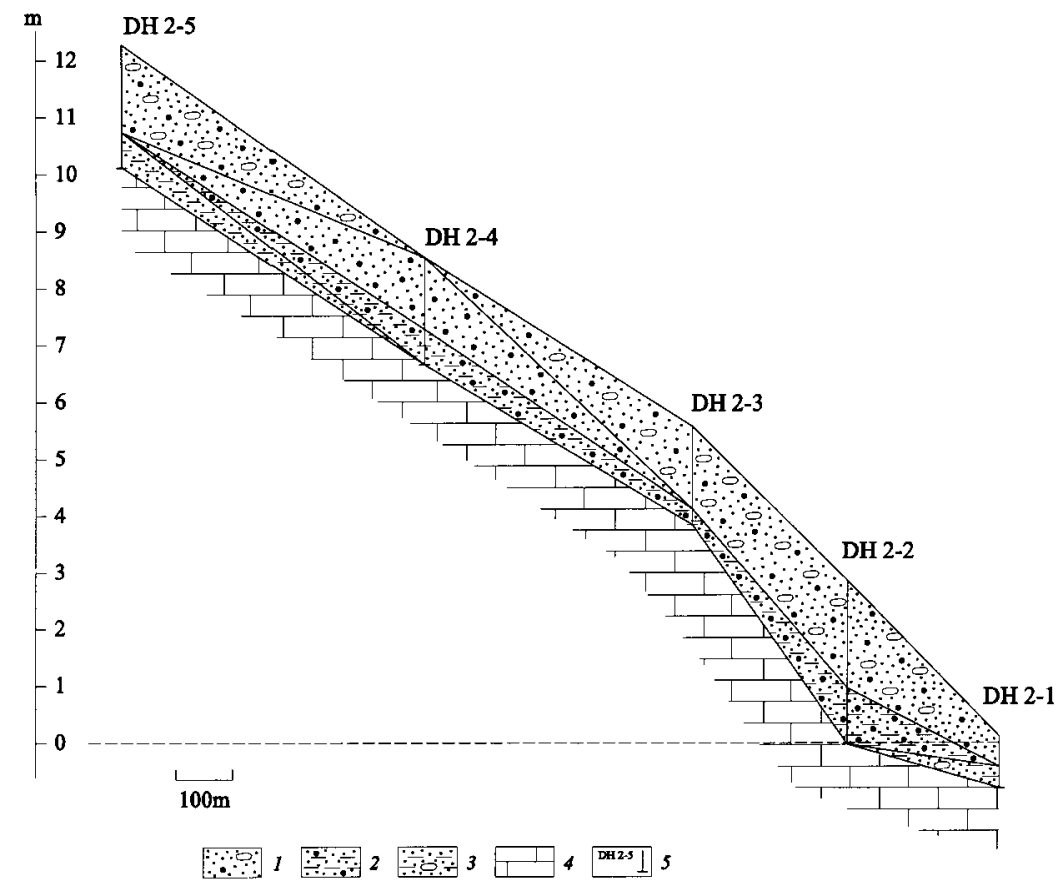

Fig. 10. Geological section of the Quaternary deposits in land area of the Suuriku-Kuriku harbour site (from $\left[{ }^{1}\right]$, modified): 1 -gravel, sand with pebbles; 2 -loam with gravel; 3 -loam with pebbles; 4 - carbonate rocks, 5 - drillholes. 
thickness of the Quaternary cover decreases again (DHs 2-3, 2-4), exceeding $2 \mathrm{~m}$ thickness in DH 2-5.

At Vaigu, thickness of the Quaternary cover is greater than at Suuriku-Kuriku. According to the cross-section compiled on the basis of drillholes (Fig. 11), sand with pebbles and loam prevail. In places, pebbles are found, limestone shingle (poorly rounded limestone pieces) occurs on contemporary beach. In DH 1-1 which was drilled during low water stand seaward of the average waterline, thickness of the Quaternary deposits is $4.10 \mathrm{~m}$. Maximum thickness is recorded in DH 1-2: $6.10 \mathrm{~m}$ (5.20 m above sea level - a.s.1.). From this point landwards, thickness of the Quaternary deposits somewhat decreases. The relatively thick Quaternary cover enables levelling of the ground surface for establishing the buildings and necessary pipelines and cables.

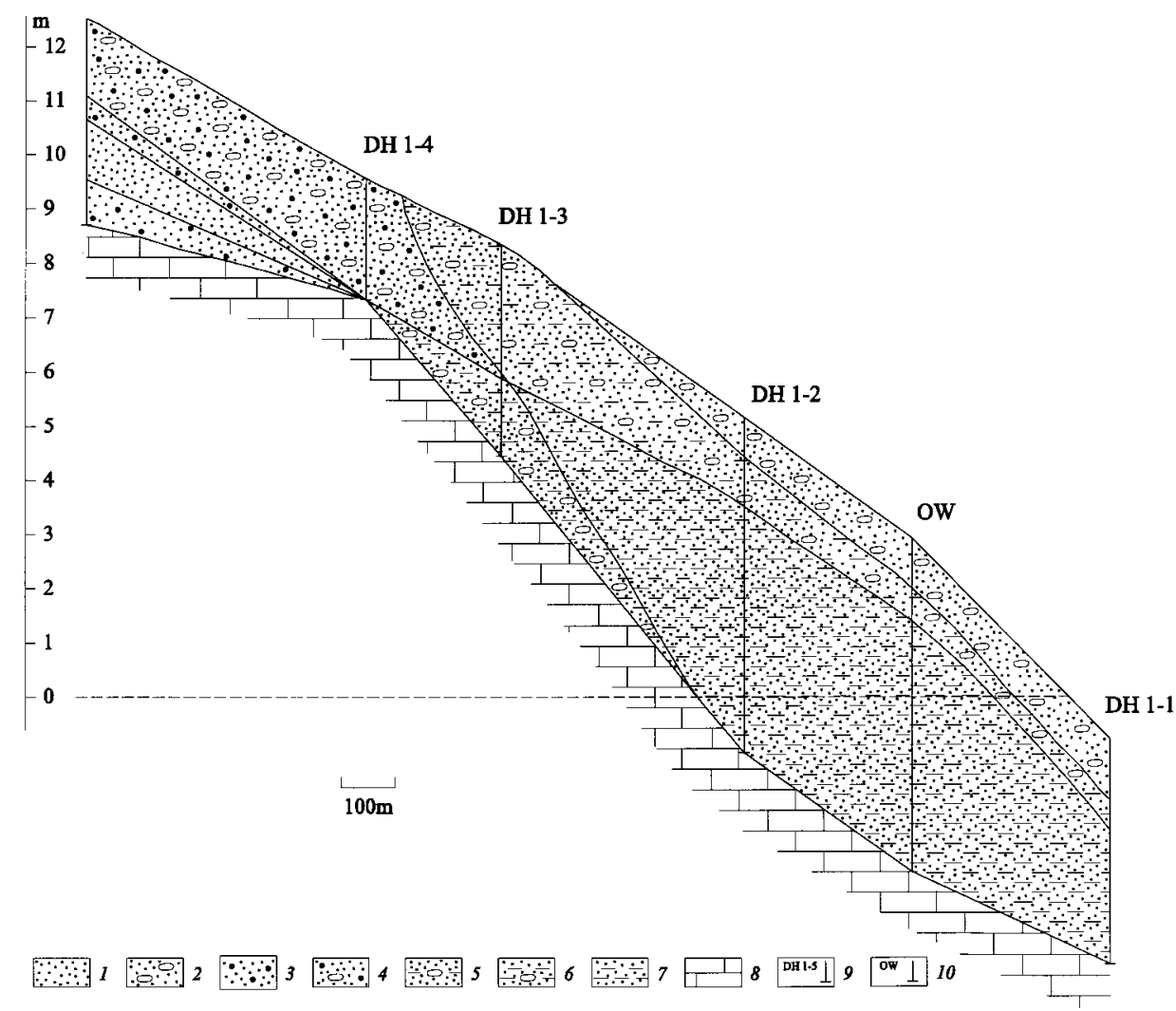

Fig. 11. Geological section of the Quaternary deposits in land area of the Vaigu harbour site (from [ $\left.{ }^{1}\right]$, modified): 1 -sand; 2 - sand with pebbles; 3 -gravel, sand; 4 -gravel, sand with pebbles; 5 -sandy loam, with pebbles; 6-loam with pebbles; 7 -loam; 8 -carbonate rocks, 9 - drillholes; 10 - observation well. 


\subsubsection{Bathymetric review of harbour basins}

Bathymetric survey in the eastern part of the Uudepanga Bay was carried out in autumn of 1999 by Arcobase Ltd., the bathymetric isolines displayed on the maps have been drawn on the basis of this survey.

At the Undva harbour site, there is wide (in the average $150 \mathrm{~m}$ to the depth of $2 \mathrm{~m}$ ) shallow limestone plateau with even surface. Farther away from the waterline, the plateau lowers gradually to the depth of $7 \mathrm{~m}$, forming stairs. Further on, the bedrock is covered with contemporary seafloor deposits and is gently sloping.

Bathymetric maps of the Suuriku-Kuriku and Vaigu harbour sites have been composed on the basis of the surveying carried out in 2000 by the Geological Survey of Estonia.

At Suuriku-Kuriku the seafloor is relatively even, the depths increasing regularly. In the southern part of the sea area, deeper than $4 \mathrm{~m}$ there is a low (about $1 \mathrm{~m}$ ) escarpment. The $10 \mathrm{~m}$ depth contour is about $350 \mathrm{~m}$ and the $20 \mathrm{~m}$ contour $650 \mathrm{~m}$ from the waterline.

At Vaigu the 1 and $2 \mathrm{~m}$ depth contours are relatively regular, while $3 \mathrm{~m}$ depth contour is less regular, especially in the area of central profiles. Between the two $5 \mathrm{~m}$ contours there is an about $250 \mathrm{~m}$ wide even area. Beginning from the $6 \mathrm{~m}$ depth contour, the seafloor inclination increases, and from the $7 \mathrm{~m}$ depth contour (about $550 \mathrm{~m}$ from the waterline) there is an escarpment (obviously, there is also a bedrock escarpment), on the approximately $75 \mathrm{~m}$ wide belt the depth increases from 7 to $20 \mathrm{~m}$.

\subsubsection{Quaternary deposits on the seafloor (harbour basins)}

In the western part of the Tagalaht Bay, the neashore marine sediments (gravel, pebbles, and cobbles) are covered with till, its thickness reaching $2 \mathrm{~m}$ in certain places (Veere harbour site).

In the central part of the Tagalaht Bay, the seafloor is covered with finegrained sand and silt $\left[{ }^{12}\right]$. In the Veere Harbour area, geophysical $\left[{ }^{13}\right]$, geological $\left[^{2}\right]$ and geotechnical investigations $\left[{ }^{14,15}\right]$ have been carried out. Drillholes made along the fairway $\left[{ }^{14,15}\right]$ show that near the shore $(150-200 \mathrm{~m}$ from waterline) the bedrock limestone is covered with till (up to $3 \mathrm{~m}$ ) and this in turn with a thin layer of sand, pebbles, and cobbles. Farther away from the waterline, the till layer wedges out and the bedrock is covered by sand with gravel or silt (at greater water depth). Although the nearshore is relatively steep, the $10 \mathrm{~m}$ depth contour is at a distance of $500 \mathrm{~m}$ from the waterline.

At Undva, bedrock is exposed on the nearshore to the depth of about $7 \mathrm{~m}$ (Fig. 12). Between the waterline and $1 \mathrm{~m}$ depth contour the bedrock surface is rather even. Between 1 and $2 \mathrm{~m}$ depth contours about $0.5 \mathrm{~m}$ deep hollows occur and farther away the bedrock surface lowers forming stairs towards the central part of the bay. At the depth of 7-8 $\mathrm{m}$, at the foot of underwater cliff there is a limestone "paving". At the depth of $8-9 \mathrm{~m}$ a belt of mixed sand with gravel, pebbles, and single boulders (maximum thickness of deposits $0.3 \mathrm{~m}$ ) is observed. 


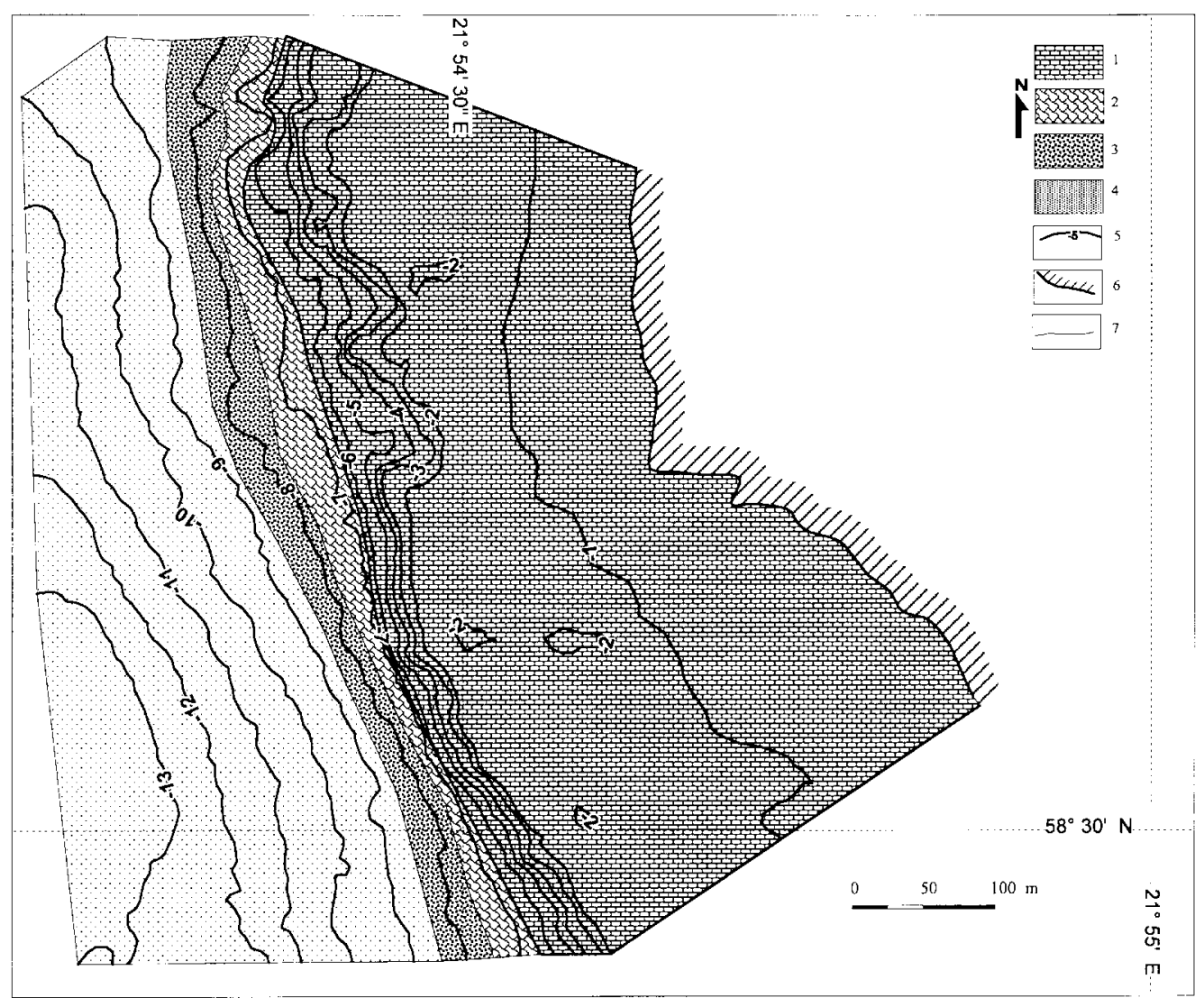

Fig. 12. Bottom deposits at the Undva harbour site (from $\left[{ }^{1}\right]$, modified): 1 - bedrock outcrop; 2 -limestone pavement; 3 -mixed sand with gravel, pebbles, and boulders; 4 -fine sand; 5 - bathymetric isoline; 6 - average waterline; 7 - margins between sediment types.

At the depth of 10-11 m, fine sand covers the seafloor, its thickness reaching $0.5 \mathrm{~m}$. By diving it was established that under the sand there is a layer $(0.5-1.0 \mathrm{~m})$ of loam, the latter covering bedrock limestone.

At Undva sidescan sonar investigations were carried out. Figure 13 shows that due to the occurrence of fractures and different hardness of rocks, the escarpment's edge has been unevenly eroded. Deeper, the limestone is covered by glacial (till), late-glacial (varved clay), and contemporary marine deposits, their total thickness reaching $1-1.5 \mathrm{~m}$.

To reduce the volume of dredging, the harbour's land area should be widened by filling, since the shallow (water depth 1-2 $\mathrm{m}$ ) neashore extends for 150-200 $\mathrm{m}$ from the waterline. Some of the dredged material (soft seafloor deposits at the depth of 7-8 m) will be dumped on the seafloor, if not suitable for filling. The southern and western parts of the Uudepanga Bay are covered with fine and medium sand. Modern technology enables dredging of limestone on fairways and in harbour basins without using explosives. In case this cannot be applied, bedrock must be crushed using small charges. 


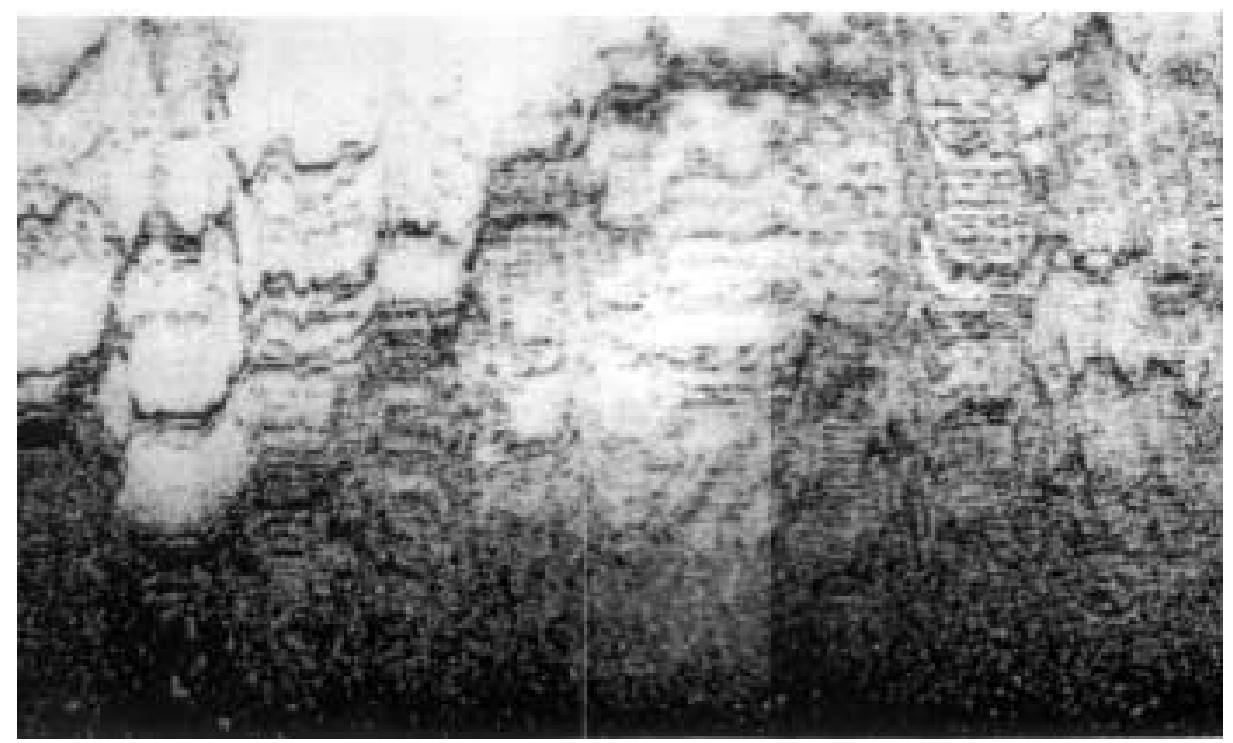

Fig. 13. Excerpt of the side-scan sonar image of the Undva harbour site(from $\left[{ }^{1}\right]$, modified). Width of the investigated belt (height of the image) is $200 \mathrm{~m}$. Light tones mark the edge of the underwater limestone escarpment (water depth 2-4 m). Darker areas indicate depth of 6-8 $\mathrm{m}$ in front of the escarpment; while above the limestone plateau the water depth ranges from 2 to $4 \mathrm{~m}$.

At the Suuriku-Kuriku harbour site, too, there is obvious connection between water depth and grain size distribution of the seafloor deposits (Fig. 14). Nearest to the waterline, to the depth of about $3 \mathrm{~m}$, there is a boulder-pebble pavement, sporadically covered with the carbonaceous shingle. At the depth of $4 \mathrm{~m}$, seafloor is covered with gravel with pebbles and few boulders, while at the depth of 5-7 $\mathrm{m}$ mixed sand with gravel is distributed. Deeper than $7 \mathrm{~m}$, fine sand occurs on the seafloor.

Distribution of the seafloor deposits at Vaigu is presented in Fig. 15. Between the waterline and the $4 \mathrm{~m}$ depth contour occurs mainly gravel with pebbles and cobbles, the latter are prevailingly made of limestone, but abundant crystalline material is present as well. At the depth of 5-6 m, mainly mixed sand is distributed with few minor areas covered with medium and fine sand. Further on, below the depth of $7 \mathrm{~m}$, seafloor is covered with fine sand.

The reason of establishing Veere Harbour at its present location is not known. It was probably supposed that Valge mägi which formerly reached farther into the sea would shelter the harbour. In this area there have been several harbour sites. The remains of the two harbours are seen on the shore at Vaigu village. Because of shallow sea, these were used only by low-draught vessels (Fig. $6^{*}$ ). By now, these harbours have been crushed by severe storms. Valge mägi coastal escarpment has been retrograding and gives therefore less protection to the Veere 


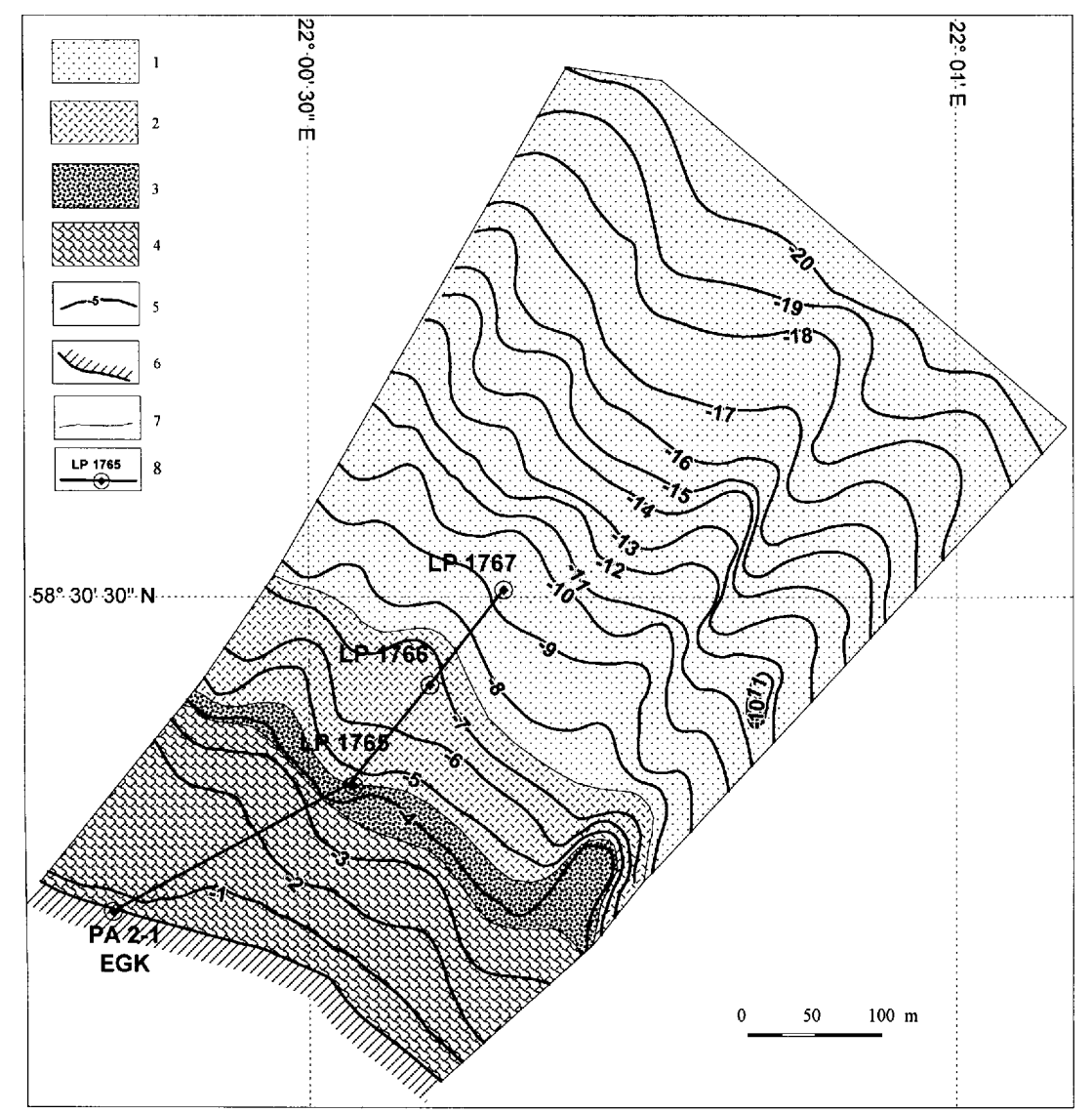

Fig. 14. Bottom deposits at the Suuriku-Kuriku harbour site (from $\left.{ }^{1}\right]$, modified): 1 - fine sand; 2 - mixed sand and gravel; 3 - gravel with pebbles and boulders; 4 - pavement of boulders and pebbles, occasionally covered with shingle; 5 -bathymetric isoline; 6 -average waterline; 7 - margins between sediment types; 8 - cross-section line, with investigation points (see Fig. 16).

Harbour. Due to shallow sea and dredging material suitable for filling, it is possible to extend the harbour into the sea. This would reduce the dredging volume of fairways and of the harbour basin, since the moles and quays would reach farther into the sea. On the other hand, that would expose the harbour constructions to much more intense wave activity.

Investigations carried out in the basins of proposed harbour sites $\left[{ }^{4}\right]$ show that at Suuriku-Kuriku the bedrock on the nearshore is covered with a thin layer of Quaternary deposits of variable grain size, while at Vaigu sand complex occurs on the nearshore, its thickness at a distance of $300 \mathrm{~m}$ from waterline exceeding $9.8 \mathrm{~m}$. 


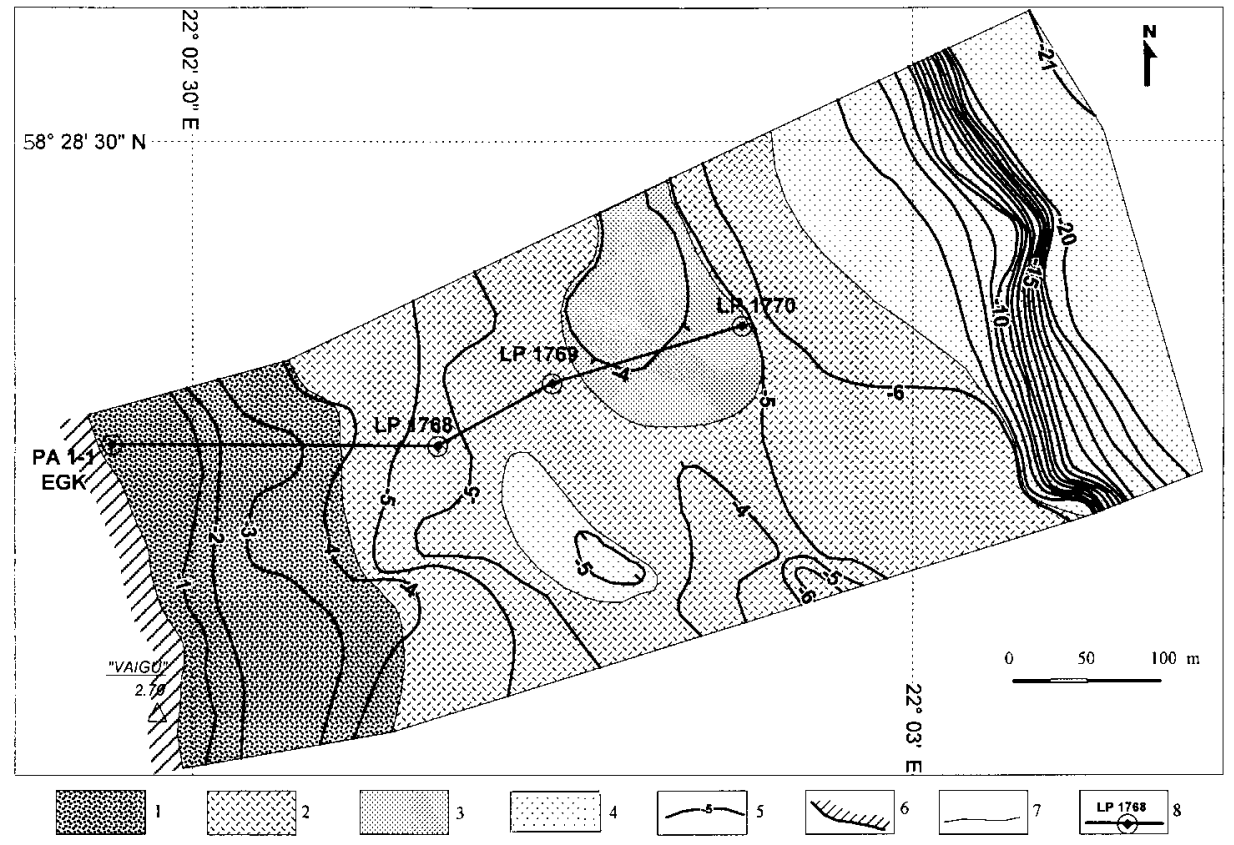

Fig. 15. Bottom deposits at the Vaigu harbour site (from $\left[{ }^{1}\right]$, modified): 1 - gravel with pebbles and cobbles; 2 -mixed sand; 3 -medium sand; 4 -fine sand; 5 -bathymetric isoline; 6 -average waterline; 7 - margins between sediment types; 8 - cross-section line, with investigation points and their numbers (see Fig. 17).

At the Suuriku-Kuriku harbour site at a distance of $400 \mathrm{~m}$ from waterline water depth is $9.4 \mathrm{~m}$. Seafloor Quaternary deposits (Fig. 16) are represented by shingle of carbonate rocks with greenish-grey loam filling, under which carbonate rocks occur. At waterline the bedrock is covered by loam containing $40-50 \%$ of pebbles (thickness $0.3 \mathrm{~m}$ in DH 2-1).

At Vaigu the bedrock surface elevation at the waterline is $-4 \mathrm{~m}$, at $200 \mathrm{~m}$ from the waterline $-9.5 \mathrm{~m}$, and at $300 \mathrm{~m}$ from the waterline less than $-14.6 \mathrm{~m}$ (Fig. 17). The carbonate rocks are covered by a sand complex (mainly silty sand), which is divided into three beds on the ground of dynamic probing test results: loose sand of varying grain size distribution (silty sand prevails) with organic matter, gravel and pebbles; medium-dense silty sand; dense silty sand.

At the waterline (DH 2-1), the carbonate bedrock is covered by a $3 \mathrm{~m}$ complex of clayly soils, comprising dark grey clay plastic loam and sandy loam. On the beach, small crystalline boulders and cobbles are found. 


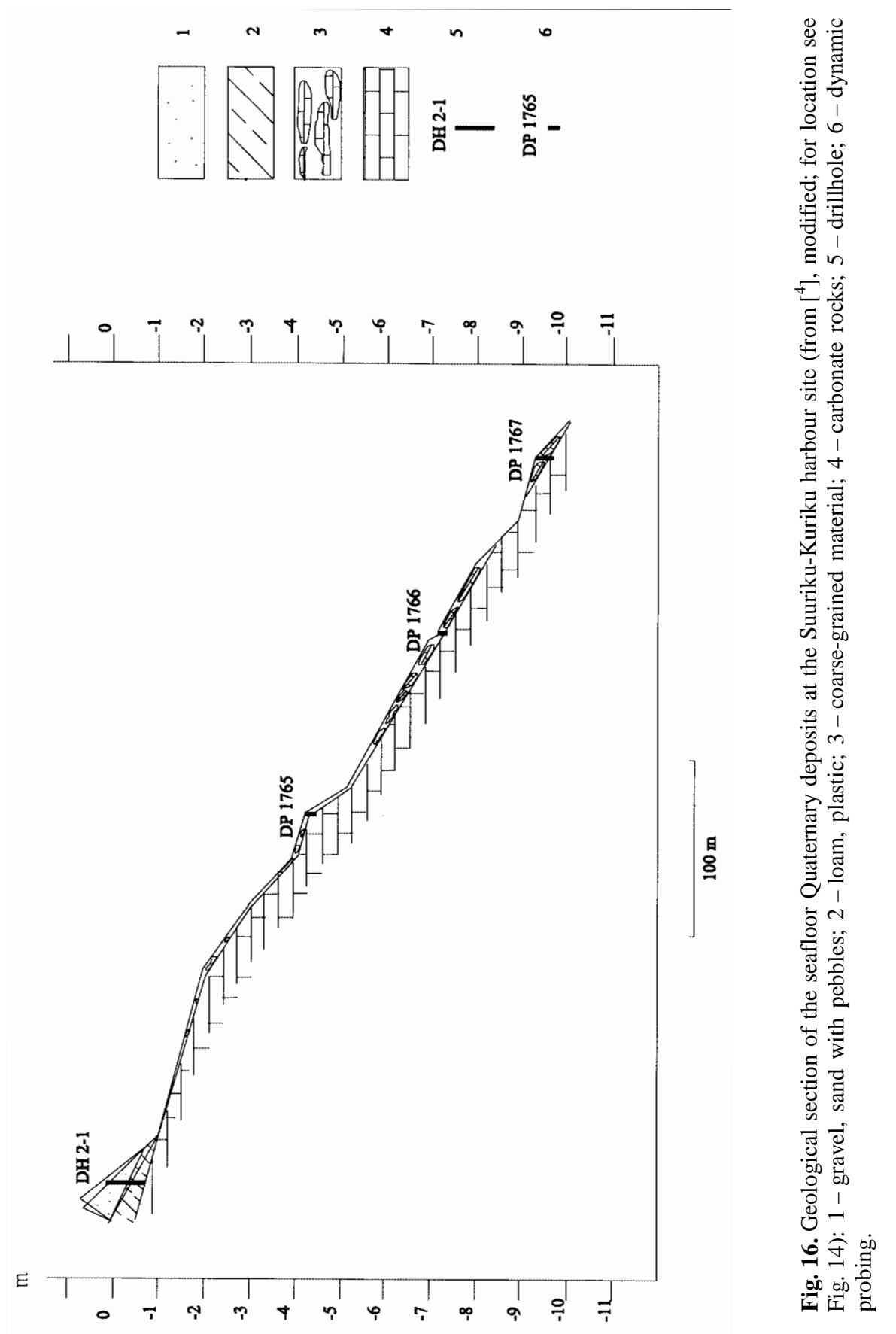




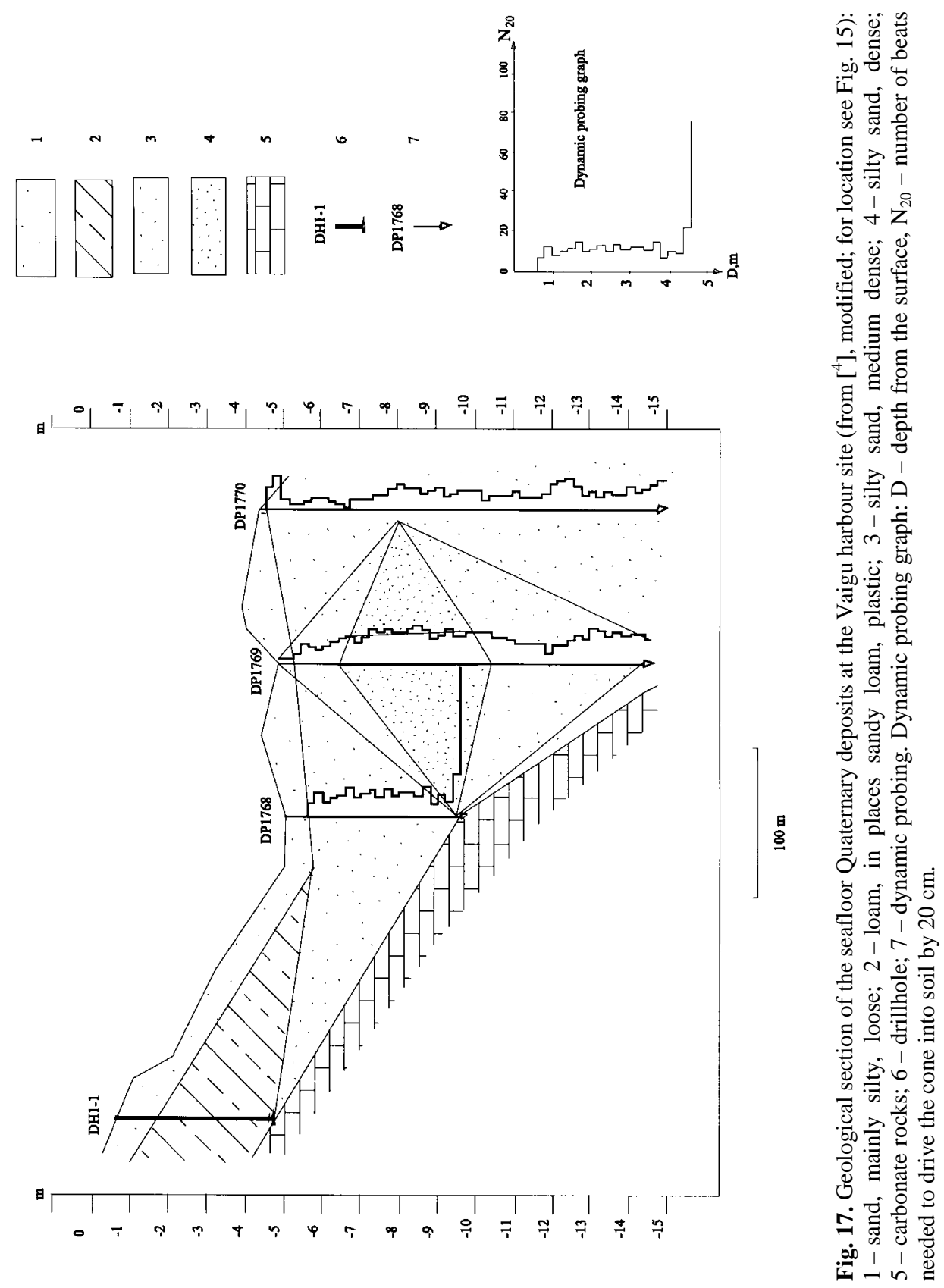




\section{HYDROGEOLOGICAL CONDITIONS}

On the Tagamõisa Peninsula, groundwater occurs mainly in the Silurian fractured carbonate rocks, forming the Silurian Aquifer. Thin till bed and gravel forming the beach ridges are mostly waterless. Within the Silurian Aquifer, the argillaceous limestones with marlstone interbeds of the Jaani Formation, Ninase Member, are major waterbearing strata. The lower portion of the Jaani Formation (marlstones of the Mustjala Member) are considered as practically impermeable aquifuge or sporadically waterbearing $\left[{ }^{6}\right]$. In the central Tagamõisa Peninsula, mostly the argillaceous limestones of the Jaagarahu Formation are waterbearing.

Groundwater recharges mostly from precipitation in the areas of bedrock elevations. Higher groundwater table elevations (above $10 \mathrm{~m}$ ) are recorded in the eastern part of the peninsula, in the surroundings of the dolomitized bioherm between Undva and Lätiniidi villages (Fig. 18*). The unevenness of ground surface and occurrence of bedrock elevations in the eastern part of the peninsula have conditioned the formation of the groundwater of different composition, and different hydraulic pressure gradient of groundwater flowing towards the Uudepanga or Tagalaht bays (Fig. $3^{*}$ ).

Because of the marine climate, the groundwater recharge in warm winters is characteristic of the Tagamõisa Peninsula. Amplitude of the groundwater level fluctuation ranges from $1 \mathrm{~m}$ (on coastal plains) to $2-3 \mathrm{~m}$ in more elevated regions. The minimum depth of the groundwater level from the ground surface depends on the duration of the dry period. The most unfavourable, from the standpoint of groundwater recharge, is winter with little snow, followed by early spring when shallow dug wells remain waterless. Generally, groundwater level in wells and drillholes is some metres from the ground surface (Fig. $3^{*}$ ).

Flowmetre logging results confirm that groundwater inflow occurs mainly from the upper portion of the aquifer to the depth of $\left.20 \mathrm{~m} \mathrm{[}{ }^{16}\right]$. Test pumping carried out in the observation area has shown that the waterbearing strata are not very abundant in water. The specific yield of drilled wells is generally below $11 /(\mathrm{s} \mathrm{m})$ and in most of the Tagamõisa Peninsula below $0.5 \mathrm{l} /(\mathrm{s} \mathrm{m})$ (Fig. 18*). Transmissivity of the aquifer is $10-50 \mathrm{~m}^{2} / \mathrm{d}$ and its hydraulic conductivity $1-5 \mathrm{~m} / \mathrm{d}$. The carbonate rocks lying below 50-60 m from the ground surface are not waterbearing in Saaremaa Island, forming over $200 \mathrm{~m}$ thick Silurian-Ordovician Aquifuge $\left[{ }^{10}\right]$.

The groundwater quality is determined by the quality of the water infiltrated from the ground surface on one hand, and by the influence of the surrounding sea on the other. Due to humid and moderately cool climate, carbonate rocks have leached and therefore in the upper portion of the Silurian Aquifer the groundwater of prevailingly $\mathrm{HCO}_{3}-\mathrm{Ca}-\mathrm{Mg}$ or $\mathrm{HCO}_{3}-\mathrm{Cl}-\mathrm{Ca}-\mathrm{Mg}-\mathrm{Na}$ composition is formed. The content of dissolved solids (TDS) is $0.3-0.7 \mathrm{~g} / 1$ [ $\left.^{17}\right]$. Deeper from the surface and especially in the vicinity of the sea, the TDS increases continuously, introducing into groundwater a $\mathrm{HCO}_{3}-\mathrm{Cl}-\mathrm{Na}$ composition with TDS $0.7-0.10 \mathrm{~g} / \mathrm{l}$. In the western part of the Tagamõisa Peninsula, groundwater is often brackish of the $\mathrm{Cl}-\mathrm{HCO}_{3}-\mathrm{SO}_{4}-\mathrm{Mg}-\mathrm{Ca}$ composition (Undva observation well) or even of $\mathrm{Cl}-\mathrm{Na}$ 
composition (for example, at the Undva border guard post). As a rule, the content of chlorides $(327.9-1462.8 \mathrm{mg} / \mathrm{l})$ and $\mathrm{Ca}(100.2-110.2 \mathrm{mg} / \mathrm{l})$ is characteristic for the groundwater in this area. The high $\mathrm{Cl}$ and $\mathrm{Ca}$ concentrations, in turn, cause the hardness exceeding the requirements of the Estonian Drinking Water Standard $11.2-11.5(\mathrm{~m}-\mathrm{eq} / \mathrm{l})\left[{ }^{18}\right]$. The major hydrogeological characteristics of the proposed harbour sites are presented in Table 1 and groundwater composition in Table 2.

Table 1. Main hydrogeological characteristics of deep harbour sites

\begin{tabular}{l|c|c|c}
\hline \multicolumn{1}{c|}{ Characteristic } & Undva & Suuriku-Kuriku & Vaigu \\
\hline Drillhole no. & 3 & 2 & 1 \\
Elevation, m & 1.6 & 12.3 & 3.0 \\
Depth, m & 10.3 & 10.2 & 10.1 \\
Depth of groundwater level, m & 0.94 & 7.85 & 3.11 \\
Dynamical groundwater level, m & 5.19 & 8.64 & 3.48 \\
Drawdown, m & 4.35 & 1.04 & 0.37 \\
Capacity, 1/s & 0.21 & 0.26 & 0.33 \\
Specific capacity, 1/(s m) & 0.05 & 0.25 & 0.90
\end{tabular}

Table 2. Groundwater composition at deep harbour sites

\begin{tabular}{|c|c|c|c|c|c|c|c|}
\hline \multirow{2}{*}{ Component } & \multicolumn{6}{|c|}{ Groundwater composition } & \multirow{2}{*}{$\begin{array}{c}\text { Maximum } \\
\text { permissible } \\
\text { concentration }\left[{ }^{18}\right]\end{array}$} \\
\hline & $\mathrm{mg} / \mathrm{l}$ & $(\mathrm{m}-\mathrm{eq}) / \mathrm{l}$ & $\mathrm{mg} / \mathrm{l}$ & $(\mathrm{m}-\mathrm{eq}) / \mathrm{l}$ & $\mathrm{mg} / \mathrm{l}$ & $(\mathrm{m}-\mathrm{eq}) / \mathrm{l}$ & \\
\hline $\mathrm{NH}_{4}^{+}$ & 0.47 & & 0.10 & & 0.51 & 0.03 & 1.0 \\
\hline $\mathrm{Na}^{+}$ & 125.0 & 5.44 & 3.5 & 0.15 & 55.6 & 2.42 & \\
\hline $\mathrm{K}^{+}$ & 20.6 & 0.53 & 2.5 & 0.06 & 4.0 & 0.10 & \\
\hline $\mathrm{Ca}^{++}$ & 100.2 & 5.00 & 65.1 & 3.25 & 96.2 & 4.80 & \\
\hline $\mathrm{Mg}^{+}$ & 79.0 & 6.50 & 21.3 & 1.75 & 43.7 & 3.60 & \\
\hline $\mathrm{Fe}_{\text {total }}$ & $<0.05$ & & 0.07 & & 0.07 & & \\
\hline Kations total & & 17.47 & & 5.21 & & 10.95 & \\
\hline $\mathrm{Cl}^{-}$ & 327.9 & 9.25 & 14.5 & 0.41 & 102.1 & 2.88 & 350.0 \\
\hline $\mathrm{SO}_{4}^{-}$ & 172.8 & 3.60 & 46.9 & 0.98 & 77.0 & 1.60 & 500.0 \\
\hline $\mathrm{NO}_{3}^{-}$ & 0.8 & 0.01 & 1.2 & 0.02 & 1.2 & 0.02 & 45.0 \\
\hline $\mathrm{NO}_{2}^{-}$ & $<0.003$ & & $<0.003$ & & $<0.003$ & & 0.1 \\
\hline $\mathrm{CO}_{3}^{-}$ & $<6.0$ & $<0.20$ & $<6.0$ & $<0.20$ & $<6.0$ & $<0.20$ & \\
\hline $\mathrm{HCO}_{3}^{-}$ & 286.8 & 4.70 & 256.3 & 4.20 & 396.6 & 6.50 & \\
\hline Anions total & & 17.56 & & 5.61 & & 11.00 & \\
\hline Total hardness & & 11.50 & & 5.00 & & 8.40 & 10.0 \\
\hline Carbonaceous hardness & & 4.70 & & 4.20 & & 6.50 & \\
\hline $\begin{array}{l}\text { Non-carbonaceous } \\
\text { hardness }\end{array}$ & & 6.80 & & 0.80 & & 1.90 & \\
\hline $\mathrm{pH}$ & & 8.0 & & & & 7.7 & $6-9$ \\
\hline $\mathrm{SiO}_{2}$ & 10.1 & & 5.6 & & 7.0 & & \\
\hline Free $\mathrm{CO}_{2}$ & 6.6 & & 11.0 & & 55.0 & & \\
\hline Oxidizability, mgO/l & 2.8 & & 0.2 & & 1.9 & & 4.0 \\
\hline Dry residue & 1070.5 & & 322.0 & & 635.0 & & 1500 \\
\hline Electrical conductivity & & $52 \mathrm{mS}$ & 0.32 & $2 \mathrm{mS}$ & & $9 \mathrm{mS}$ & \\
\hline
\end{tabular}


The vertical as well as lateral zonality of the groundwater was formed mainly due to the surrounding sea and palaeogeographical conditions in the Holocene. During the Holocene the whole Tagamõisa Peninsula was flooded by the Litorina Sea, the salinity of which $(8-15 \%$ ) considerably exceeded that of the Baltic Sea water near the Tagamõisa Peninsula. Intrusion of saline seawater into the bedrocks resulted in the formation of brackish groundwater. After the regression of the sea, as a result of infiltration of precipitation and surface water, the groundwater became less brackish.

Under natural condition the fresh groundwater and saline seawater are hydrodynamically balanced, which controls also the diffusion belt causing the distribution of chlorides. Intense groundwater consumption may result in disturbing the above balance. Therefore possible intrusion of brackish groundwater must be taken into account when establishing groundwater intakes. In the western part of the peninsula the ground surface is lower and the groundwater pressure gradient smaller, therefore the possibility of seawater intrusion is greater (Fig. 18*).

From the standpoint of groundwater vulnerability, the whole Tagamõisa Peninsula is unprotected, since thickness of the Quaternary cover is everywhere less than $2 \mathrm{~m}$. Numerous alvars are exposed areas, from where the surface pollution easily reaches the groundwater. Presently, there is no intense agricultural activity on the Tagamõisa Peninsula and its influence on the groundwater is insignificant. Also the content of nitrate compounds in the consumption water wells is small.

Considering that the Tagamõisa Peninsula is an unprotected area, the harbour establishments should be designed in the way that avoids any accidental infiltration of pollutants into the groundwater.

The Ordovician-Cambrian Aquifer System occurs in Undva key drillhole under the Silurian-Ordovician Aquifuge at the depth of $269.4 \mathrm{~m}$. The waterbearing strata are the Lower and Middle Cambrian sand- and siltstones. By lithological characteristics, the aquifer system is divided into the Ruhnu $\left(\epsilon_{2} r h\right)$ and Soela-Tiskre $\left(\epsilon_{1} s l-\epsilon_{1} t s\right)$ aquifers, separated by the Irben $\left(\epsilon_{1} i r\right)$ Aquifuge $\left[{ }^{19}\right]$. At test pumping, carried out in Undva key drillhole in 1971, the groundwater of the Ordovician-Cambrian Aquier System was not separated from the Lower Cambrian Voosi Aquifer. Therefore the groundwater in the Cambrian sandstones is characterized jointly.

Piezometric level in a drillhole depends on the ground surface elevation. In Undva key drillhole, the piezometric water level reached $3 \mathrm{~m}$ above the ground surface, the latter being $7.5 \mathrm{~m}$ a.s.l. The water yield at $9.7 \mathrm{~m}$ drawdown was $8.01 / \mathrm{s}\left(28.8 \mathrm{~m}^{3} / \mathrm{h}\right.$ or $\left.691.2 \mathrm{~m}^{3} / \mathrm{d}\right)$. Thus, in all proposed harbour sites the required amount of groundwater could be produced from the Ordovician-Cambrian Aquifer System. However, the content of chlorides and sodium exceeds the maximum permissible concentrations. Content of chlorides at test pumping was $498.9 \mathrm{mg} / \mathrm{l}$ (maximum permissible concentration by Estonian Drinking Water Standard $\left[{ }^{18}\right]-350 \mathrm{mg} / \mathrm{l}$, European Union requirements - $250 \mathrm{mg} / \mathrm{l}$ ) and content 
of $\mathrm{Na}+\mathrm{K}$ was $328.2 \mathrm{mg} / \mathrm{l}$ (EU requirements $-200 \mathrm{mg} / \mathrm{l}$ ). The above high concentrations of chlorides and sodium are characteristic of all tested aquifers. Results of test pumping in Kuressaare town indicate that in the lower part of the aquifer system the TDS is up to twice higher $\left[{ }^{20}\right]$. However, fresh groundwater, meeting the requirements of the Estonian Drinking Water Standard, has been obtained from the upper portion of the aquifer system on southern Hiiumaa Island, Muhu Island, in Pöide village on Saaremaa Island, etc. Similarly, also on the Tagamõisa Peninsula it is possible to produce fresh groundwater from the upper part of the Ordovician-Cambrian Aquifer System.

\section{DISCUSSION}

\subsection{Engineering-geological conditions on the seafloor of harbour sites}

At Undva harbour site the engineering-geological conditions for establishing the mole and quays are good. Most of these will be based on carbonate bedrock of good bearing capacity. Dredging of the bedrock is complicated. The geotechnical characteristics in Table 3 are obtained by the dynamic probing test correlations $\left[{ }^{4}\right]$ and on the basis of former investigation results. Soil classification according to dredging categories $\left[{ }^{21}\right]$ is presented in Table 4.

Table 3. Geotechnical properties of soils

\begin{tabular}{|c|c|c|c|c|c|}
\hline Soil & $\begin{array}{c}\gamma, \\
\mathrm{kN} / \mathrm{m}^{3}\end{array}$ & $\begin{array}{c}E, \\
\mathrm{MPa}\end{array}$ & $\begin{array}{c}\varphi, \\
\operatorname{deg}\end{array}$ & $\begin{array}{c}c \\
\mathrm{kPa}\end{array}$ & $\begin{array}{c}R_{c} \\
\mathrm{MPa}\end{array}$ \\
\hline \multicolumn{6}{|c|}{ Undva } \\
\hline Coarse-grained soil & 22 & 10 & 22 & 10 & \\
\hline Carbonate rocks & 25 & & & & 50 \\
\hline \multicolumn{6}{|c|}{ Suuriku-Kuriku } \\
\hline Sand & 17 & 6 & 23 & 0 & \\
\hline Loam & 19 & 5 & 22 & 10 & \\
\hline Coarse-grained soil & 22 & 10 & 22 & 10 & \\
\hline Carbonate rocks & 25 & & & & 50 \\
\hline \multicolumn{6}{|c|}{ Vaigu } \\
\hline Sand, loose & 17 & 3 & 24 & 0 & \\
\hline $\begin{array}{l}\text { Loam (in places sandy } \\
\text { loam), plastic }\end{array}$ & 19 & 7 & 24 & 10 & \\
\hline Silty sand, medium dense & 19 & 11 & 26 & 4 & \\
\hline Silty sand, dense & 20 & 30 & 34 & 5 & \\
\hline Carbonate rocks & 25 & & & & 50 \\
\hline $\begin{array}{l}\text { bulk density } \\
\text { modulus of compressibility } \\
\text { angle of internal friction } \\
\text { cohesion }\end{array}$ & & & & & \\
\hline
\end{tabular}


Table 4. Dredging categories of soils and rocks (from $\left[{ }^{11}\right]$ )

\begin{tabular}{|c|c|c|c|}
\hline Soil & $\begin{array}{c}\text { Grain size } \\
\text { distribution class } \\
\end{array}$ & $\begin{array}{c}\text { Excavation } \\
\text { category }\end{array}$ & $\begin{array}{l}\text { Dumping } \\
\text { category }\end{array}$ \\
\hline \multicolumn{4}{|c|}{ Undva } \\
\hline Coarse-grained soil & II & VI & 1 \\
\hline Carbonate rocks & - & VII & 3 \\
\hline \multicolumn{4}{|c|}{ Suuriku-Kuriku } \\
\hline Coarse-grained soil & II & VI & 1 \\
\hline Carbonate rocks & - & VII & 3 \\
\hline \multicolumn{4}{|c|}{ Vaigu } \\
\hline Sand, loose & III & III & 2 \\
\hline $\begin{array}{l}\text { Loam (in places sandy } \\
\text { loam), plastic }\end{array}$ & $\mathrm{V}$ & IV & 1 \\
\hline Silty sand, medium dense & III & IV & 1 \\
\hline Silty sand, dense & III & IV & 2 \\
\hline Carbonate rocks & & VII & 3 \\
\hline
\end{tabular}

At the Suuriku-Kuriku harbour site the engineering-geological conditions for establishing the mole and quays are good, since these will be based on carbonate bedrock which is of good bearing capacity. Dredging of the bedrock is complicated and expensive. Establishing of jetties partly at the depth of 10-16 m requires a great amount of the filling material. Shore processes in the area are rather intense (erosion of the Suuriku Cliff and transport of the eroded material southward), therefore it is likely that in the area northward of the designed jetty sediments will be accumulated. The related characteristics are presented in Tables 3 and 4.

At the Vaigu harbour site engineering-geological conditions for establishing the mole and quays are satisfactory. The bearing capacity of soils (mainly finegrained sand) is sufficient as for the load resulting from the harbour buildings. Engineering-geological conditions for establishing the mole and supporting walls of quays considerably improve at a distance of $250 \mathrm{~m}$ from the waterline. Dredging conditions are favourable, the dredged sand can be used for filling. Due to occurrence of sands in the harbour basin, the dredged area will likely be filled with sediments in time.

\subsection{Engineering-geological conditions in land areas of harbour sites}

To raise the ground surface, great amount of fill is needed at all harbour sites. At Vaigu and Suuriku-Kuriku the ground surface elevation is presently 2-2.5 m and at Undva below $1 \mathrm{~m}$ a.s.l. Thus to raise the harbour sites to the required level (3.5 $\mathrm{m}$ a.s.l.), extensive filling is needed.

Undva harbour site is located on an alvar with less than $1 \mathrm{~m}$ of the Quaternary cover and the ground surface elevation ranges from 0.1 to $1.5 \mathrm{~m}$ a.s.l. Huge 
amount of fill is needed to raise the ground surface. The driveway must be extended, but due to flat surface the area can be easily levelled. The harbour buildings will be established on carbonaceous rocks.

At Suuriku-Kuriku the Quaternary deposits are represented mainly by pebbles, shingle, and gravel. Width of the relatively even area (1.5-3 $\mathrm{m}$ a.s.l.) is $50-60 \mathrm{~m}$. Dredged material as well as the sediments removed to obtain the required inclination of the driveway can be used to fill the area up to the required $3.5 \mathrm{~m}$ a.s.l. Engineering-geological conditions for establishing the harbour constructions as well as the bearing capacity of soils and rocks is good. Thickness of the Quaternary cover is smaller than at Vaigu.

Vaigu harbour site is situated above a beach ridge system, thickness of the Quaternary cover ranging from $1-1.5 \mathrm{~m}$ on the waterline to about $5 \mathrm{~m}$ in the landward side of the area. The area is easily levelled due to about $2 \mathrm{~m}$ thick layer of terrigenous sediments. To reduce the driveway's inclination, the loose Quaternary sediments are easily removed. Engineering-geological conditions for establishing the buildings are good, gravel with pebbles and cobbles is of sufficient bearing capacity.

\section{CONCLUSIONS}

At the Undva harbour site there is a smooth limestone plateau where the thickness of the Quaternary cover is small or missing in places (Table 5). The topmost part of the sedimentary bedrock is made of the biohermal complex of the Jaani Stage. The upper part of the latter consisting of argillaceous limestone with bioherms is suitable for utilizing as fill, while its lower $2 \mathrm{~m}$ part made of strong pure limestone can be used as building material or for producing splinters (Table 6). The pure limestone level is easily recognizable in all sections of the region.

Table 5. Depth of the bedrock surface and thickness of the Quaternary cover in proposed harbour sites, $\mathrm{m}\left(\right.$ from $\left.\left[{ }^{1}\right]\right)$

\begin{tabular}{|c|c|c|c|c|c|c|}
\hline \multirow[b]{2}{*}{$\begin{array}{l}\text { Distance from } \\
\text { waterline }\end{array}$} & \multicolumn{2}{|c|}{ Undva } & \multicolumn{2}{|c|}{ Suuriku-Kuriku } & \multicolumn{2}{|c|}{ Vaigu } \\
\hline & $\begin{array}{l}\text { Elevation of } \\
\text { bedrock } \\
\text { surface }\end{array}$ & $\begin{array}{c}\text { Thickness of } \\
\text { Quaternary } \\
\text { cover }\end{array}$ & $\begin{array}{c}\text { Elevation } \\
\text { of bedrock } \\
\text { surface }\end{array}$ & $\begin{array}{c}\text { Thickness of } \\
\text { Quaternary } \\
\text { cover }\end{array}$ & $\begin{array}{c}\text { Elevation } \\
\text { of bedrock } \\
\text { surface }\end{array}$ & $\begin{array}{c}\text { Thickness of } \\
\text { Quaternary } \\
\text { cover }\end{array}$ \\
\hline $400 \mathrm{~m}$ towards sea & $>-11$ & $<1.2$ & $>-15$ & $>10.5$ & -12.2 & 0.25 \\
\hline $300 \mathrm{~m}$ towards sea & $>-8$ & missing & $>-15$ & $>9.7$ & -9.1 & 0.25 \\
\hline $200 \mathrm{~m}$ towards sea & -6 & missing & -9.7 & 4.7 & -7.5 & 0.25 \\
\hline At waterline & -0.1 & 0.1 & -4.5 & 4.1 & -0.6 & 0.75 \\
\hline $100 \mathrm{~m}$ towards land & 0.6 & 0.3 & 4.5 & 3.8 & 6.7 & 1.8 \\
\hline $150 \mathrm{~m}$ towards land & 0.7 & 0.9 & 8.7 & 3.8 & 10.2 & 2.1 \\
\hline
\end{tabular}


Table 6. Approximate uniaxial compressive strength of carbonate rocks in water-saturated state, $\mathrm{MPa}$ (from $\left[{ }^{10}\right]$ )

\begin{tabular}{ccccc}
\hline Distance from waterline & Undva & Suuriku-Kuriku & Vaigu \\
\hline 400 m toward sea & $40-50$ & $20-30$ & $30-50$ \\
300 m toward sea & $50-60$ & $30-40$ & $30-50$ \\
$200 \mathrm{~m}$ toward sea & $50-80$ & $40-50$ & $60-80$ \\
At waterline & $60-80$ & $50-60$ & $50-60$ \\
$100 \mathrm{~m}$ toward land & $60-80$ & $50-80$ & $50-80$ \\
$150 \mathrm{~m}$ toward land & $40-60$ & $50-60$ & $50-80$
\end{tabular}

In the harbour basin area, the biohermal complex occurs to the depth of 5-8 $\mathrm{m}$. In the central part of the bay, marlstones of the Jaani Stage crop out. Majority of the harbour basin will be dredged in the carbonate bedrock either by ramming or blasting. The dredged material can be used for filling the land area or inner part of the jetty. Extensive dredging is required. Shore processes are more intensive as compared with Vaigu, but less intensive than at Suuriku-Kuriku. The biohermal exposure northward of the harbour site must be preserved due to its palaeontological and bedrock geological value.

Bedrock geological setting of the Suuriku-Kuriku harbour site is similar to Undva, but the bedrock surface relief is different, the site being located between the waterline and the 10-12 m high coastal escarpment. Between the Suuriku and Kuriku cliffs, the biohermal complex of the Jaani Stage has retrograded, since its less resistant argillaceous part has been abraded by the sea. Thickness of the Quaternary cover on the cliff is $1-2 \mathrm{~m}$.

At the harbour basin area, the Quaternary cover is made prevailingly of carbonate shingle and mixed-grained sediments. At the waterline, the bedrock is covered by loam containing $40-50 \%$ of pebbles (thickness $0.3 \mathrm{~m}$ ) and sand with gravel and pebbles (thickness $0.5 \mathrm{~m}$ ). On the shore marine sediments of various gain size are distributed. Due to the small thickness of the Quaternary cover in the area (Table 5), the harbour basin will be dredged in relatively soft marlstone (Table 6). In the deeper part of the basin the marlstone can be loosened by blasting using weak charges, while in the shallow part ramming can be applied. As compared with Undva and Vaigu, the dredging volume is the smallest. Building of the driveway has to be planned as well. As compared with other sites, shore processes in the area are the most intensive (abrasion of the Suuriku Cliff and transport of the abraded material southward). Therefore it is likely that sediments will be intensely accumulated northward of the designed jetty.

Suuriku Cliff is one of the few cliffs in Estonia where the biohermal complex of the Jaani Stage is exposed and therefore it must not be damaged. Being an important part of the Silurian reef belt, the cliff has been inserted into the Book of Primeval Nature of Estonia.

At the Vaigu harbour site the thickness of the Quaternary deposits ranges from 2 to $6 \mathrm{~m}$. Down to the depth of $15 \mathrm{~m}$, the bedrock is represented by the 
argillaceous limestones of the Jaani Stage with biohermal complex in the lower part.

In the harbour basin the carbonate bedrocks are covered by a sand complex, its thickness exceeding $10 \mathrm{~m}$. At the waterline the Quaternary deposits consist of plastic loam (thickness $3.0 \mathrm{~m}$ ) below sand $(1.0 \mathrm{~m})$. Thickness of the Quaternary deposits at the Vaigu harbour site is bigger than at Undva and Suuriku-Kuriku, therefore the dredging volume is the biggest. On the other hand, due to soft sediments the loosening of rocks is not needed. The dredged material can be used for filling. Due to the distribution of sands in the harbour basin area, these may in time be carried back to the dredged area. Intensity of shore processes is lower than at the Undva and Suuriku-Kuriku harbour sites.

From the hydrogeological point of view, the deep harbour can be established at any of the proposed sites.

On the eastern coast of Uudepanga Bay, groundwater is related mainly to the argillaceous limestones and marlstones of the Jaani Stage. More abundant in water are the horizontal fractures at the contact of argillaceous and pure limestone. The capacity of a $3.2 \mathrm{~m}$ deep shaft established on the shore was $1.5 \mathrm{l} / \mathrm{s}$ at $2.5 \mathrm{~m}$ drawdown. The capacity of a $10.1 \mathrm{~m}$ deep observation well was $0.2 \mathrm{l} / \mathrm{s}$ at $4.35 \mathrm{~m}$ drawdown and its specific capacity $0.05 \mathrm{l} /(\mathrm{s} \mathrm{m})$. Since the rocks are not water-abundant, the excavations for harbour constructions can be isolated from seawater if needed.

At the Suuriku-Kuriku and Vaigu harbour sites, the rocks are more abundant in water. Specific capacities of 10.2 and $10.1 \mathrm{~m}$ observation wells were 0.25 and $0.901 /(\mathrm{s} \mathrm{m})$, respectively (Table 1), which is below the average water-abundance of the Silurian Aquifer on Saaremaa Island (specific capacity of drilled wells is prevailingly $1-5 \mathrm{l} /(\mathrm{s} \mathrm{m})$ ).

Thus, in all investigated harbour sites the water-abundance of rocks is moderate.

Groundwater quality is a more concerning problem than water-abundance. At Suuriku-Kuriku and Vaigu up to $50 \mathrm{~m}^{3}$ groundwater per day is guaranteed, but at Undva supplementary investigations are needed because of the brackish groundwater.

From the Ordovician-Cambrian Aquifer System lying at a depth of 260-270 $\mathrm{m}$ from the surface, sufficient amount of groundwater $\left(>50 \mathrm{~m}^{3} / \mathrm{d}\right)$ can be produced at all proposed harbour sites. However, the content of chlorides and sodium exceeds the maximum permissible concentrations and needs therefore detailed investigations.

Considering the above-said, it can be concluded that in spite of active shore processes, geological and hydrogeological conditions for establishing the harbour are somewhat more favourable between the Suuriku and Kuriku cliffs than at Undva. It should be noted that dredging volumes as well as the amount of filling material needed for jetties and quays have not been taken into account. At Undva dredging would be more work-consuming and to produce fresh high-quality drinking water is more complicated. Vaigu harbour site was considered less 
favourable because on the harbour basin area a thick complex of sand occurs on the seafloor.

\section{ACKNOWLEDGEMENTS}

This investigation was financed by the Estonian Ministry of Environment. The authors are grateful to the colleagues from the Geological Survey of Estonia: T. Parm and H. Luht who performed computer graphics, J. Kivisilla who read the manuscript and made valuable suggestions and critical comments, and S. Peetermann for linguistic help, and A. Talpas for assistance during the field work.

\section{REFERENCES}

1. Elken, J., Soomere, T., Kask, J., Kõuts, T., Liiv, U., Perens, R., and Rõõm, R. Saaremaa süvasadama võimalike asukohtade hüdrodünaamilised ja geoloogilised uuringud. Eesti Mereinstituut, Tallinn, 2000.

2. Orviku, K., Lutt, J., Palginõmm, V., and Mäss, E. Vyyavit' stroenie i vliyanie antropogennogo faktora na razvitie zalivov Zapadno-Éstonskogo arhipelaga $v$ poslednie 2800 let. Institute of Geology, Acad. Sci. Estonian SSR, Tallinn, 1987 (in Russian).

3. Noormets, R. Quaternary deposits in the Baltic Sea west of Estonia: Preliminary results of a seismic reflection survey. Proc. Estonian Acad. Sci. Geol., 1994, 43, 18-31.

4. Kildjer, P. Süvasadama asukoha valik Saaremaal. Saaremaa, Kihelkonna vald. OÜ REI Geotehnika, Tallinn, 2000.

5. Raukas, A. Purdkivimite terasuuruse klassifikatsioon. Eesti NSV Tead. Akad. Geoloogia Instituut, Tallinn, 1981.

6. Perens, R., All, T., and Lelgus, M. Siluri karbonaatkivimite veejuhtivusest Saaremaal vooluhulga karotaazhi andmetel. Eesti Geoloogiakeskuse Toimetised, 1994, 4, 1, 36-43.

7. Nestor, H. Catalogue of Silurian Stratigraphic Units and Stratotypes in Estonia and Latvia. Baltic Stratigraphic Association, Estonian Acad. Sci., Institute of Geology, Tallinn, 1993.

8. Perens, H. Jaani ja Jaagarahu lademe piirikihtidest Saaremaal. Eesti Geoloogiakeskuse Toimetised, 1995, 5, 1, 12-19.

9. Nestor, H. Silurian. In Geology and Mineral Resources of Estonia (Raukas, A. and Teedumäe, A., eds.). Estonian Academy Publishers, Tallinn, 1997, 89-106.

10. Perens, R. and Perens, H. Geoloogilised uuringud Suure väina tunneli rajamise tasuvushinnangute tegemiseks. Eesti Geoloogiakeskus, Tallinn, 1998.

11. Orviku, K. Contemporary shore. In Vyyavit' stroenie $i$ vliyanie antropogennogo faktora na razvitie zalivov Zapadno-Éstonskogo arhipelaga v poslednie 2800 let. Institute of Geology, Acad. Sci. Estonian SSR, Tallinn, 1987, 29-39 (in Russian).

12. Lutt, J. Bottom deposits. In Vyyavit' stroenie $i$ vliyanie antropogennogo faktora na razvitie zalivov Zapadno-Éstonskogo arhipelaga v poslednie 2800 let. Institute of Geology, Acad. Sci. Estonian SSR, Tallinn, 1987, 56-119 (in Russian).

13. Kuten, N. Engineering-geophysical investigations of the fairway of Veere Harbour. Unicone Ltd., Riga, 1993 (in Russian).

14. Torn, H. Veere sadama faarvaatri geotehnilised tingimused. OÜ Geotehnika Inseneribüroo, Tallinn, 1997.

15. Kildjer, P. Veere sadama laiendus. Saaremaa, Kihelkonna vald. OÜ REI Geotehnika, Tallinn, 2000.

16. Perens, R., Perens, H., and Lelgus, M. Saaremaa kompleksse geoloogilise kaardistamise mõ̃tkavas 1:50 000 aruanne. Eesti Geoloogiakeskus, Tallinn, 1994. 
17. Perens, R. Saaremaa hüdrogeokeemiast. In Eesti geoloogiline ehitus ja maavarad: sümpoosiumi materjalid (Puura, I., Kalm, V., Kivisilla, J., Klein, V., Puura, V., Raudsep, R., and Riet, K., eds.). Eesti Geoloogia Selts, Tallinn, 1991, 87-88.

18. Joogivesi. Üldnõuded. EVS 663:1995. Eesti Standardiamet, Tallinn, 1995.

19. Perens, R. and Vallner, L. Water-bearing formation. In Geology and Mineral Resources of Estonia (Raukas, A. and Teedumäe, A., eds.). Estonian Academy Publishers, Tallinn, 1997, 137-144.

20. Tassa, V. and Perens, H. Kuressaare mineraalvee otsing ja eeluuring. Eesti Geoloogiakeskus. Tallinn, 1990.

21. Temporary price list for seafloor dredging. Ministerstvo Morskovo Flota, Moscow, 1984 (in Russian).

\section{LOODE-SAAREMAA VÕIMALIKE SADAMAKOHTADE GEOLOOGILISE EHITUSE VÕRDLUS}

\section{Jüri KASK, Helle PERENS, Rein PERENS, Sten SUUROJA ja Andres KASK}

Uuringu eesmärk oli Saaremaa süvasadamale sobivaima asukoha leidmine arvestades hüdrogeoloogilisi ja geoloogilisi tingimusi. Tulenevalt Keskkonnaministeeriumi tellitud uuringu lähteülesandest käsitleti kolme alternatiivi: Suuriku-Kuriku sadamakoht ja Vaigu sadamakoht Tagalahe läänerannikul ning Undva sadamakoht Uudepanga lahe idarannikul.

Suuriku-Kuriku sadamakohas paikneb sadamaala mere ja 10-12 m kõrguse pangaastangu vahel. Pinnakatte paksus pangal on 1-2 m. Lahe põhi jääb Jaani lademe merglite avamusele. Sadamakoha akvatooriumis on väga õhuke pinnakate esindatud valdavalt karbonaatkivimitest klibu ja segateraliste setetega. Veepiiril lasub aluspõhjakivimitel $0,3 \mathrm{~m}$ paksuselt veeristega liivsavi ning $0,5 \mathrm{~m}$ kruusa ja veeristega liiva. Ranna ääres on sadamaala valdavaks pinnakatteks mitmesuguse terajämedusega merelised setted. Sadamabasseinide rajamiseks tuleb süvendada suhteliselt pehmet merglit (survetugevus 40-60 MPa). Süvendamismaht on kolmest sadamakohast väikseim. Juurdesõidutee on vaja rajada järsu nõlva sisse. Tõenäoline on, et aktiivsete rannaprotsesside tõttu täitub rajatavast lainemurdjast põhja poole jääv mereosa setetega.

Vaigu sadamakohas on pinnakatte paksus 2-6 m. Aluspõhja moodustavad kuni $15 \mathrm{~m}$ sügavuseni Jaani lademe savikad lubjakivid koos all oleva biohermikompleksiga. Akvatooriumis katab aluspõhja 4,5-10,0 m paksune liivpinnaste kompleks, veepiiril aga plastne liivsavi $(3 \mathrm{~m})$, millel lasub $1 \mathrm{~m}$ liiva. Suurem pinnakatte paksus tähendab mahukaid süvendustöid sadama rajamiseks, kuid pehmet pinnast ei ole vaja kobestada. Liivade esinemise tõttu meres eksisteerib rajatud süvendite täitumise oht. Rannaprotsessid on väheaktiivsed.

Undva sadamakohas on planeeritav sadamaala peaaegu ilma pinnakatteta tasane paeplatoo, mille geoloogilise läbilõike ülemise osa (4-8 m) moodustab Jaani lademe biohermse kompleksi muutliku savikusega lubjakivi; kompleksi alumine, $2 \mathrm{~m}$ paksune osa koosneb tugevast puhtast lubjakivist (survetugevus 60-80 MPa). Vee all avaneb biohermne kompleks 5-8 $\mathrm{m}$ sügavusel. Lahe 
keskmine osa jääb pehmete Jaani lademe merglite (survetugevus 40-60 MPa) avamusalale. Valdav osa sadamabasseinist tuleb rajada karbonaatkivimitesse ja süvendustööde maht on suur. Rannaprotsessid on väheaktiivsed.

Kvaliteetse joogivee saamise võimalused on keerulisemad Uudepanga lahe ääres, kus mere läheduse tõttu on põhjavesi kohati kloriidirikas ja soolakas. Suuriku ja Kuriku panga vahel ning Vaigu rannas on mageda põhjavee saamine (kuni $50 \mathrm{~m}^{3} /$ ööp.) võimalik ilma hüdrogeoloogiliste lisauuringuteta, Uudepanga lahe ääres nõuab veehaarde rajamine suuremaid investeeringuid. 260-270 m sügavusel lasuvast kambriumi põhjaveekompleksist on võimalik saada piisav kogus vett (rohkem kui $50 \mathrm{~m}^{3} /$ ööp.) kõigis sadamakohtades, kuid esimesena nimetatud veekompleksi vee suur kloriidide ja naatriumi sisaldus vajab veel uurimist.

Vaatamata suhteliselt aktiivsetele rannaprotsessidele on sadama rajamine Suuriku ja Kuriku panga vahele geoloogiliselt ning hüdrogeoloogiliselt mõnevõrra soodsam kui Undvasse (jättes siinkohal arvestamata süvendamismahu ning lainemurdjate ja kaide täitematerjali hulga). Undva sadamakohas on kivimid raskemini läbitavad ning kvaliteetse joogivee saamise võimalused komplitseeritumad. Vaigu randa sadama rajamine on teiste sadamakohtadega võrreldes ebasoodsam, sest seal on meres paks liivakiht. 